\title{
Nitrogen dynamics and phytoplankton community structure: the role of organic nutrients
}

\author{
Grigorios Moschonas 1 - Richard J. Gowen • Ruth F. Paterson • \\ Elaine Mitchell • Brian M. Stewart • Sharon McNeill • Patricia M. Glibert • \\ Keith Davidson
}

Received: 26 September 2016/ Accepted: 7 June 2017/Published online: 15 June 2017

(C) The Author(s) 2017. This article is an open access publication

\begin{abstract}
Dissolved organic nitrogen (DON) is recognised as an important $\mathrm{N}$ source for phytoplankton. However, its relative importance for phytoplankton nutrition and community composition has not been studied comprehensively. This study, conducted in a typical Scottish fjord, representative of nearpristine coastal environments, evaluates the utilisation of DON and dissolved inorganic nitrogen (DIN) by different microbial size fractions and the relationship of phytoplankton community composition with DON and other parameters. The study demonstrated that DON was important in supporting phytoplankton throughout the yearly production cycle. The higherthan-expected urea uptake rates and large fraction of the spring bloom production supported by DON
\end{abstract}

Responsible Editor: Leila J. Hamdan.

G. Moschonas $(\varangle)$ - R. J. Gowen · R. F. Paterson •

E. Mitchell $\cdot$ S. McNeill $\cdot$ K. Davidson

Scottish Association for Marine Science, Argyll,

Oban PA37 1QA, Scotland, UK

e-mail: mos.greg@gmail.com

R. J. Gowen · B. M. Stewart

Fisheries and Aquatic Ecosystems Branch, Agriculture Food and Environmental Science Division, Agri-Food and Biosciences Institute, Newforge Lane, Belfast BT9 5PX, UK

P. M. Glibert

Horn Point Laboratory, University of Maryland Center for Environmental Science, PO Box 775, Cambridge,

MD 21613, USA suggested that organic $\mathrm{N}$ not only contributes to regenerated production and to the nutrition of the small phytoplankton fraction, but can also contribute substantially to new production of the larger phytoplankton in coastal waters. Multivariate statistical techniques revealed two phytoplankton assemblages with peaks in abundance at different times of the year: a spring group dominated by Skeletonema spp., Thalassiosira spp., and Pseudo-nitzschia spp. group delicatissima; and a summer/autumn group dominated by Chaetoceros spp., Scrippsiella spp., and Pseudonitzschia spp. group seriata. The multivariate pattern in community composition and abundance of these taxa was significantly correlated with the multivariate pattern of DON, urea, dissolved free amino acids, DIN, temperature, salinity, and daylength, with daylength and urea being particularly important, suggesting both physical and chemical controls on community composition.

Keywords Dissolved organic nitrogen · Phytoplankton · Nitrogen uptake $\cdot$ Community composition

\section{Introduction}

It is important to understand the processes that influence phytoplankton community composition and abundance, in the context of both natural phytoplankton species 
succession (Smayda 1980) and undesirable disturbance (Tett et al. 2007). Nitrogen $(\mathrm{N})$, as nitrate $\left(\mathrm{NO}_{3}{ }^{-}\right)$, nitrite $\left(\mathrm{NO}_{2}{ }^{-}\right)$, and ammonium $\left(\mathrm{NH}_{4}{ }^{+}\right)$, has historically been considered the main limiting nutrient for phytoplankton growth and biomass in coastal waters (Howarth 1998; Howarth and Marino 2006; Ryther and Dunstan 1971; Vitousek and Howarth 1991). As such, it is potentially a principal determinant of phytoplankton community composition and abundance: changes in the concentration (Gowen et al. 2012a), ratio to other nutrients, and proportion of different chemical forms (Davidson et al. 2012) of $\mathrm{N}$ can lead to changes in phytoplankton community composition and abundance (Gowen et al. 2012a; Glibert et al. 2016 and references therein), potentially promoting the growth of harmful species (Glibert et al. 2005) or altering the carbon export flux of coastal seas (Bronk et al. 2007).

Dissolved organic N (DON) is also increasingly recognized as an $\mathrm{N}$ source for phytoplankton. Up to $\sim 70 \%$ of DON in the marine environment may be bioavailable (Berman and Bronk 2003; Bronk 2002; Sipler and Bronk 2015) in labile (e.g. urea, amino acids) and semi-labile forms (Glibert et al. 2006), but it was previously considered a substrate that predominantly supported bacterial production (Bronk et al. 2007; Zehr and Ward 2002). However, DON, especially urea, which is used in nitrogenous fertilisers and can contribute to anthropogenic nutrient enrichment, has been linked to the growth of phytoplankton including harmful algal blooms (HABs) (Anderson et al. 2002; Glibert et al. 2005, 2006, 2014a). Dissolved free amino acids (DFAA), as well as peptides, have also been demonstrated to be important for phytoplankton nutrition (see Mulholland and Lomas 2008; Mulholland and Lee 2009).

Although it is increasingly clear that DON serves as an $\mathrm{N}$ source for both bacteria and phytoplankton (Antia et al. 1991; Bronk et al. 2007; Lønborg et al. 2009b; Pete et al. 2010), there is little information on the relative utilisation of different forms of inorganic and organic $\mathrm{N}$ over an annual cycle or possible links to phytoplankton community composition (Glibert et al. 1982a, 2016 and references therein, Davidson et al. 2014, 2012).

The utilisation of different forms of DON by different phytoplankton species and size fractions and its effect on phytoplankton community composition has not been studied comprehensively, especially using rigorous statistical techniques to support observations. Now that we know that autotrophs utilise DON in competition with heterotrophs, and that DON concentrations globally are significant, with a mean of $4.4 \pm 0.5 \mu \mathrm{mol} \mathrm{N} \mathrm{L}{ }^{-1}$ (Letscher et al. 2013), a major research question is which organisms are utilising the different forms of organic N, when, and in what form (Sipler and Bronk 2015). Different features of DON biogeochemistry have been studies around the British Isles (e.g. Davidson et al. 2013; Fitzsimons et al. 2011; Moschonas et al. 2015; Tappin et al. 2010). The areas around the British Isles where DON has been studied are the North Sea, English Channel Irish Sea and adjacent shelf as well as English estuaries and Scottish fjordic sea-lochs (for examples of studies in each area see Moschonas et al. (2015)). Few of the studies, however, have directly measured $\mathrm{N}$ uptake by the microbial community.

The objectives of this study were therefore to evaluate the importance of DON for phytoplankton nutrition relative to that of inorganic $\mathrm{N}$ in two different microbial community size fractions $(<$ and $>10 \mu \mathrm{m})$ and to identify patterns in phytoplankton community composition and abundance associated with chemical and physical factors using rigorous statistical analysis. We chose to conduct this study in Loch Creran, Scotland, because it represents a near-pristine coastal location, providing a useful baseline for the study of anthropogenic pressures on coastal ecosystems; and many aspects of its hydrography, biology, and chemistry have been previously studied (Booth 1987; Fehling et al. 2006; Lønborg et al. 2009b; Tett et al. 2011) allowing the new knowledge generated in this study to be placed in a wider context.

\section{Methods}

Sampling

Sampling was carried out between 18 January and 12 December 2012 from the Scottish Association for Marine Science (SAMS) research vessel Seol Mara, at a sampling station $\left(56^{\circ} 31^{\prime} \mathrm{N}, 5^{\circ} 22.6^{\prime} \mathrm{W}\right)$ in Loch Creran (Fig. 1). Sampling was conducted in daylight before noon on 20 different dates at roughly 2 week intervals, sufficient to resolve the major events in the annual cycle of plankton such as the spring bloom. Vertical profiles of temperature, conductivity, and photosynthetically active radiation were recorded at each station using a SBE 19 CTD (Sea-Bird 
Fig. 1 Map of Loch Creran with sampling station (St) and adjacent geography

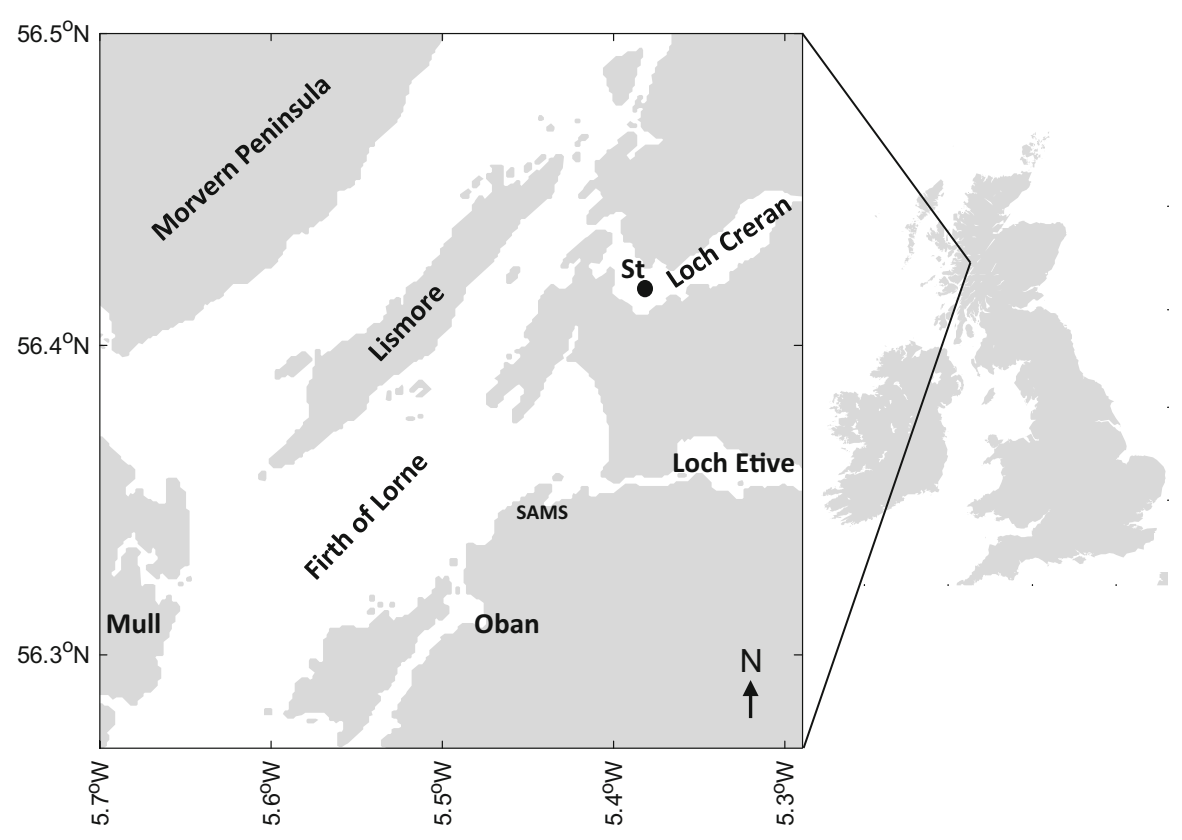

Electronics). Practical salinity (dimensionless) and in situ temperature were converted to absolute salinity $\left(\mathrm{g} \mathrm{kg}^{-1}\right)$, conservative temperature $\left({ }^{\circ} \mathrm{C}\right)$, and potential density $\left(\mathrm{kg} \mathrm{m}^{-3}\right)$ per the International Thermodynamic Equation of Seawater 2010 in the Gibbs SeaWater Oceanographic Toolbox (IOC et al. 2010; McDougall and Barker 2011). Accordingly, the salinity variable in this study is absolute salinity with units of $\mathrm{g} \mathrm{kg}^{-1}$, rather than practical salinity which is dimensionless (McDougall and Barker 2011). Temperature and salinity values are presented hereafter as average potential temperature and average absolute salinity for the upper $25 \mathrm{~m}$ of the water column. Water was collected using a $5 \mathrm{~L}$ Niskin-type bottle from the depth of the fluorescence maximum (if present), or $10 \mathrm{~m}$. Water was immediately pre-filtered $(200 \mu \mathrm{m}$ mesh) to exclude larger zooplankton, and was stored for $\sim 1$ to $1.5 \mathrm{~h}$ in opaque thermally insulated polypropylene containers until return to the laboratory.

\section{Chemical analyses}

The pre-filtered water was used for the determination of urea, DFAA, and dissolved inorganic nutrient concentrations. On return to the laboratory the water sample was filtered through pre-combusted 10 or $25 \mathrm{~mm}$ glass fibre filters (PALL A/E, 0.7-1 $\mu \mathrm{m}$ nominal pore size prior to combustion) using clean plastic syringes, and stored frozen in polyethylene acid-washed sample bottles at $-20{ }^{\circ} \mathrm{C}$ until analysis. Dissolved inorganic nutrients were analysed on a five Channel QuAAtro autoanalyser (Seal Analytical), configured for the simultaneous determination of dissolved inorganic $\mathrm{N}$ (DIN), silicon (DIS) and phosphorus (DIP) in sea water (Seal Analytical, 2011a, b, c, d, e).

Urea analysis was performed using the manual diacetyl monoxime method (Mulvenna and Savidge 1992), adapted for room temperature (Goeyens et al. 1998), use of a single reagent, and low sample volumes (Revilla et al. 2005). The working reagent was made up of 1 part of solution A (diacetylmonoxime, thiosemicarbazide) and 3.2 parts of solution B (sulphuric acid, ferric chloride) as described in Revilla et al. (2005). Samples were allowed to thaw overnight, then $4 \mathrm{~mL}$ of each replicate were transferred to $15 \mathrm{~mL}$ polypropylene centrifuge tubes, the reagent added and the solutions mixed by vortex before being incubated at $22{ }^{\circ} \mathrm{C}$ in the dark for $72-84 \mathrm{~h}$ (Goeyens et al. 1998). Subsequently, absorbance was measured by spectrophotometry at $520 \mathrm{~nm}$ on an Evolution $300 \mathrm{UV}-$ Vis Spectrophotometer (Thermo Scientific).

Total DFAA concentrations were determined by the $o$-phthalaldehyde fluorometric method (Parsons et al. 1984), optimised for the use of 3-mercaptopropionic acid in the reagent, as this gives better 
reliability than mercaptoethanol (Aminot and Kérouel 2006). The working reagent was made up of $20 \mathrm{~mL}$ of solution A (o-phthalaldehyde, ethanol), $400 \mathrm{~mL}$ of solution $\mathrm{B}$ ( $\mathrm{pH}$ adjusted ortho-boric acid solution) and $1 \mathrm{~mL} 3$-mercaptopropionic acid as described in the above studies. Samples were allowed to thaw overnight, and $5 \mathrm{~mL}$ of each replicate transferred to $15 \mathrm{~mL}$ polypropylene centrifuge tubes. Following reagent addition, each solution was vortex mixed and allowed to stand for $2 \mathrm{~min}$ before its fluorescence was measured on a Trilogy laboratory fluorometer (Turner Designs). Calibration was with glycine standards and the DFAA concentrations were expressed as a glycine equivalent (Parsons et al. 1984; Tada et al. 1998).

Determination of dissolved organic carbon (DOC) and DON concentrations followed on-board filtration through pre-combusted $25 \mathrm{~mm}$ glass fibre filters (0.7-1 $\mu \mathrm{m}$ nominal pore size prior to combustion), using acid-washed glass syringes, acidified with $50 \mu \mathrm{L}$ $85 \%$ orthophosphoric acid. Samples were stored in sealed pre-combusted glass containers at $4{ }^{\circ} \mathrm{C}$ in the dark until analysis (Davidson et al. 2007). This was performed using high temperature catalytic oxidation with non-dispersive infrared and chemiluminescence detections on a Shimadzu TOC-Vcph total organic carbon (TOC) module connected to a Shimadzu TNM-1 total N (TN) module. When samples are filtered, TDN is measured by the TN module. For each run the measurements were quality checked with a deep seawater reference (Florida Strait at $700 \mathrm{~m}$, batch 9-2009, 41-44 $\mu \mathrm{mol} \mathrm{L}{ }^{-1}$ DOC, 32.25-33.75 $\mu \mathrm{mol} \mathrm{L}^{-1}$ TN). Concentrations of DOC were determined directly after the acidified samples were sparged with air to remove dissolved inorganic carbon. Concentrations of DON were calculated indirectly by subtracting DIN from TDN, and the propagated error was calculated by combining errors in quadrature (Taylor 1997).

For the determination of chlorophyll (Chl) concentrations, one batch of samples was filtered directly through pre-combusted $47 \mathrm{~mm}$ glass fibre filters (PALL A/E, 0.7-1 $\mu \mathrm{m}$ nominal pore size prior combustion) under gentle vacuum $(<100$ to $150 \mathrm{mmHg}$ pressure differential), while a second batch was first filtered through pre-washed polycarbonate membranes $(10 \mu \mathrm{m}$ pore size $)$, to retain the $>10 \mu \mathrm{m}$ size fraction with only the filtrate then being secondary filtered through pre-combusted $47 \mathrm{~mm}$ glass fibre filters (PALL A/E, 0.7-1 $\mu \mathrm{m}$ nominal pore size) in an identical manner to above. All samples were stored frozen at $-20{ }^{\circ} \mathrm{C}$ in $15 \mathrm{~mL}$ centrifuge tubes until analysis. Prior to analysis, pigments were extracted in 90\% neutralised acetone overnight, then Chl concentration was determined on a Trilogy fluorometer (Turner Designs) using the $\mathrm{Chl}$ acidification technique and corrected for phaeopigments (Arar and Collins 1997).

\section{Phytoplankton enumeration}

Water samples for phytoplankton identification and enumeration were fixed with Lugol's iodine solution to $1 \%$ final concentration, and stored refrigerated in opaque amber plastic bottles. Prior to identification, $50 \mathrm{~mL}$ aliquots from each sample were settled in Hydro Bios chambers for 20-24 h, then examined under a Carl Zeiss Axiovert inverted microscope at $\times 20$ magnification. Authorities for genera and species were taken from WoRMS (2016). Phytoplankton cells were identified to genus, or species level where possible, and abundance values were expressed as number of cells $\mathrm{L}^{-1}$. Morphotype groups of the genera Pseudo-nitzschia Peragallo (Fehling et al. 2006) and Chaetoceros Ehrenberg (Hasle and Syvertsen 1997) were also identified.

Size fractionated $\mathrm{N}$ uptake of nitrate, ammonium, urea and DFAA

Uptake rates of $\mathrm{N}$ were determined using the ${ }^{15} \mathrm{~N}$ tracer technique (Dugdale and Wilkerson 1986; Glibert and Capone 1993). After a $1.5 \mathrm{~h}$ transit to the laboratory, water was transferred into transparent $250 \mathrm{~mL}$ polycarbonate bottles. Sets of four bottles received one of ${ }^{15} \mathrm{~N}$ labelled $(98+\%) \mathrm{NH}_{4} \mathrm{Cl}, \mathrm{NaNO}_{3}$, urea, and an algal amino acid mixture (SigmaAldrich). We aimed to achieve a tracer concentration of $10 \%$ of ambient $\mathrm{N}$ concentration (Dugdale and Goering 1967), estimated from historical N concentrations at the sampling station; as a result, the tracer concentrations rarely exceeded $20 \%$ of ambient. Immediately after the tracer additions, bottles were incubated in tanks with flow-through seawater drawn continuously from the sea to simulate in situ temperature and covered with appropriate light filters to simulate in situ light intensity. Following a $2-2.25 \mathrm{~h}$ incubation, half of the replicates for each ${ }^{15} \mathrm{~N}$ labelled compound were filtered at $<100-150 \mathrm{mmHg}$ pressure differential directly through pre-combusted $25 \mathrm{~mm}$ 
glass fibre filters (PALL A/E; 0.7-1 $\mu \mathrm{m}$ nominal pore size before combustion), while the other half were first filtered through pre-washed polycarbonate membranes $(10 \mu \mathrm{m}$ pore size $)$, and then through precombusted $25 \mathrm{~mm}$ glass fibre filters to retain the $<10 \mu \mathrm{m}$ size fraction. Goldman and Dennett (1985) found that avoiding air exposure of filters minimises intracellular material loss from cell stress. Therefore, for each sample, when most of the water had filtered through, and before the filter was exposed to air (as in Goldman and Dennett 1985), it was rinsed with 'aged' filtered seawater to wash away any residual dissolved nutrients (Glibert and Capone 1993; Lipschultz 2008). Filters were stored frozen at $-20{ }^{\circ} \mathrm{C}$ in the dark until analysis.

Prior to analysis, the samples were thawed at room temperature, dried overnight at $60{ }^{\circ} \mathrm{C}$, and then folded into tin foil capsules (Sercon). Particulate organic carbon (POC), particulate organic N (PON), and the $\mathrm{N}$ stable isotope composition of each sample were measured on a PDZ Europa 20-20 Stable Isotope Analyser connected to an ANCA-NT system, calibrated with L-Isoleucine standards (Sigma-Aldrich) and modified for analysis of low mass samples (Owens and Rees 1989). Absolute and specific $\mathrm{N}$ uptake rates were calculated per Dugdale and Wilkerson (1986). The calculation was not corrected for isotope dilution (Glibert et al. 1982b; Kanda et al. 1987) by $\mathrm{N}$ regeneration, which could result in an underestimate of the $\mathrm{NH}_{4}^{+}$and urea uptake rates (Glibert et al. 1982b; Hansell and Goering 1989).

\section{Statistical analysis}

Multivariate patterns of phytoplankton community composition and abundance and their relationship to environmental variables were analysed by applying Multidimensional Scaling (MDS), Hierarchical Agglomerative Clustering (Cluster), and Spearman rank correlation (BIO-ENV) coupled to permutation (RELATE) analysis on Bray-Curtis similarity matrices of sample or taxon standardised data on the software package PRIMER (Clarke and Ainsworth 1993; Clarke 1993; Clarke and Green 1988).

To statistically select groups of phytoplankton with similar patterns in seasonal distribution, namely taxa that increased with time, cluster analysis was applied to a between-taxon Bray-Curtis similarity matrix. This matrix was generated from taxon-standardised abundance of a subset of the 'most important' taxa, that is, the taxa that contributed the most to the abundance of each sample. This subset was limited to 15 taxa, which removed the 'rarer' taxa and enabled the effective between-taxa analysis. The removal of the rarer taxa is necessary for the statistical exploration of species similarities (Clarke and Ainsworth 1993; Clarke 1993; Clarke and Green 1988).

Following the selection of taxa belonging to different groups, their abundances were $\log (x+1)$ transformed to balance the influence of low and high abundances of taxa on multivariate patterns. Then, MDS analysis was applied to the between-sample Bray-Curtis similarity matrix generated from the transformed abundances to visualise the multivariate pattern in community composition and abundance. The similarity matrix generated from the selected subset of taxa was compared to a similarity matrix of all enumerated taxa. This revealed that the multivariate pattern of community composition and abundance based on the subset of taxa was representative of that based on all enumerated taxa. It was then analysed for statistical correlation with a number of environmental variables by applying BIO-ENV.

\section{Results}

From all measured environmental variables that could influence phytoplankton community composition (Table 1), seven (Table 2) significantly correlated $(\mathrm{p}<0.02)$ with the multivariate pattern of community composition and abundance. From the 10 best correlations, the variables that emerged as dominant were urea, daylength, temperature, DFAA, DON, salinity, and DIN (Table 2).

These seven environmental variables had distinct seasonal patterns (Fig. 2). Concentrations of DIN were highest in winter, decreased in April after the spring bloom, and remained low until the end of August and then increased to winter levels (Fig. 2b). $\mathrm{NO}_{3}{ }^{-}$concentrations accounted for most of the seasonal variability in DIN while $\mathrm{NH}_{4}{ }^{+}$concentrations remained relatively stable around $0.5 \mu \mathrm{mol} \mathrm{N} \mathrm{L}{ }^{-1}$ throughout the year except for a peak in late summer/early autumn. Concentrations of DON were high in winter, autumn and mid-summer, and low in late spring and late summer (Fig. 2c). Urea concentrations reflected the mid-summer highs of DON concentrations, but had 
Table 1 Environmental variables that could influence phytoplankton community composition and abundance and were included in the multivariate analyses

\begin{tabular}{ll}
\hline Variable & Units \\
\hline DIN & $\mu \mathrm{mol} \mathrm{N} \mathrm{L}{ }^{-1}$ \\
DON & $\mu \mathrm{mol} \mathrm{N} \mathrm{L}{ }^{-1}$ \\
Urea & $\mu \mathrm{mol} \mathrm{N} \mathrm{L}^{-1}$ \\
DFAA & $\mu \mathrm{mol} \mathrm{N} \mathrm{L}^{-1}$ \\
DOC & $\mu \mathrm{mol} \mathrm{L}^{-1}$ \\
DIP & $\mu \mathrm{mol} \mathrm{L}^{-1}$ \\
DIS & $\mu \mathrm{mol} \mathrm{L}^{-1}$ \\
Temperature & ${ }^{\circ} \mathrm{C}^{-1}$ \\
Salinity & $\mathrm{g} \mathrm{kg}^{-1}$ \\
Light attenuation & $\mathrm{m}^{-1}$ \\
Density difference $1-25 \mathrm{~m}$ & $\mathrm{~kg} \mathrm{~m}^{-3}$ \\
Tidal range & $\mathrm{m}$ \\
Daylength & $\mathrm{h}$ \\
\hline
\end{tabular}

only a single high value in winter (Fig. 2d). Concentrations of DFAA were higher in early spring and midsummer with a single high value in winter at the same time as urea (Fig. 2e). Temperature was lowest in March and highest in late August. Salinity was lowest with relatively high fluctuations in autumn and winter, and highest with relatively small fluctuations in spring and summer. Daylength was lowest on the winter Solstice in December and highest on the summer Solstice in June.
The taxa enumerated by light microscopy were larger diatoms and dinoflagellates (mostly $>10 \mu \mathrm{m}$ in diameter), and their collective abundance in Loch Creran is referred to hereafter as phytoplankton abundance, POC concentrations as microbial biomass and $\mathrm{Chl}$ concentrations as phytoplankton biomass. Morphotype groups of the genera Pseudo-nitzschia Peragallo (Fehling et al. 2006) and Chaetoceros Ehrenberg (Hasle and Syvertsen 1997) were also identified. Microbial biomass, phytoplankton biomass and phytoplankton abundance in Loch Creran in 2012 were highest in spring with smaller blooms evident in summer and late autumn (Fig. 3). POC and Chl concentrations of the $<10 \mu \mathrm{m}$ size fraction remained relatively stable $\left(74-171 \mu \mathrm{g} \mathrm{POC} \mathrm{L}^{-1}\right.$ and 0.01-0.8 $\mu \mathrm{g} \mathrm{Chl} \mathrm{L}^{-1}$ ) throughout the year compared to the $>10 \mu \mathrm{m}$ fraction $\left(29-325 \mu \mathrm{g} \mathrm{POC} \mathrm{L}^{-1}\right.$ and $0-7.3 \mu \mathrm{g} \mathrm{Chl} \mathrm{L}^{-1}$ ). However the former made a substantial contribution $(21-73 \%$ for POC and 6-100\% for $\mathrm{Chl}$ ) to total microbial biomass (1-200 $\mu \mathrm{m}$ size fraction): higher when biomass was low, but lower during the spring and summer/autumn blooms, for which the $>10 \mu \mathrm{m}$ fraction was mainly responsible (Fig. 3a, b). Diatom abundance as a percentage of total phytoplankton abundance exceeded $85 \%$ in all samples (Fig. 3c).

The presence and timing of maximum abundance of different diatom and dinoflagellate taxa varied seasonally (Table 3). The predominant diatoms and dinoflagellates were Skeletonema spp. Greville and

Table 2 Results of BEST analysis $(\mathrm{p}<0.02)$

\begin{tabular}{|c|c|c|c|c|c|c|c|}
\hline $\begin{array}{l}\text { Spearman rank } \\
\text { correlation }\end{array}$ & $\begin{array}{l}\text { DIN } \\
\left(\mu \mathrm{mol} \mathrm{N} \mathrm{L}{ }^{-1}\right)\end{array}$ & $\begin{array}{l}\text { DON } \\
\left(\mu \mathrm{mol} \mathrm{N} \mathrm{L}{ }^{-1}\right)\end{array}$ & $\begin{array}{l}\text { Urea } \\
\left(\mu \mathrm{mol} \mathrm{N} \mathrm{L}{ }^{-1}\right)\end{array}$ & $\begin{array}{l}\text { DFAA } \\
\left(\mu \mathrm{mol} \mathrm{N} \mathrm{L}{ }^{-1}\right)\end{array}$ & $\begin{array}{l}\text { Temperature } \\
\left({ }^{\circ} \mathrm{C}\right)\end{array}$ & $\begin{array}{l}\text { Salinity } \\
\left(\mathrm{g} \mathrm{kg}^{-1}\right)\end{array}$ & $\begin{array}{l}\text { Daylength } \\
\text { (h) }\end{array}$ \\
\hline 0.580 & & & X & & X & & X \\
\hline 0.548 & & X & X & & $X$ & & $X$ \\
\hline 0.547 & & & $X$ & $X$ & $X$ & & $X$ \\
\hline 0.542 & & X & X & X & $X$ & & X \\
\hline 0.541 & & & X & & & & X \\
\hline 0.538 & & & X & & X & X & $X$ \\
\hline 0.518 & & $X$ & $X$ & & $X$ & $X$ & $X$ \\
\hline 0.517 & & & X & X & $X$ & X & X \\
\hline 0.513 & X & & X & $X$ & $X$ & & X \\
\hline 0.513 & $X$ & & X & & $X$ & & X \\
\hline
\end{tabular}

The 10 best correlations between the multivariate pattern of community composition and abundance and environmental variables. For each correlation, the variables whose multivariate pattern resulted in the correlation are denoted by $\mathrm{X}$ 


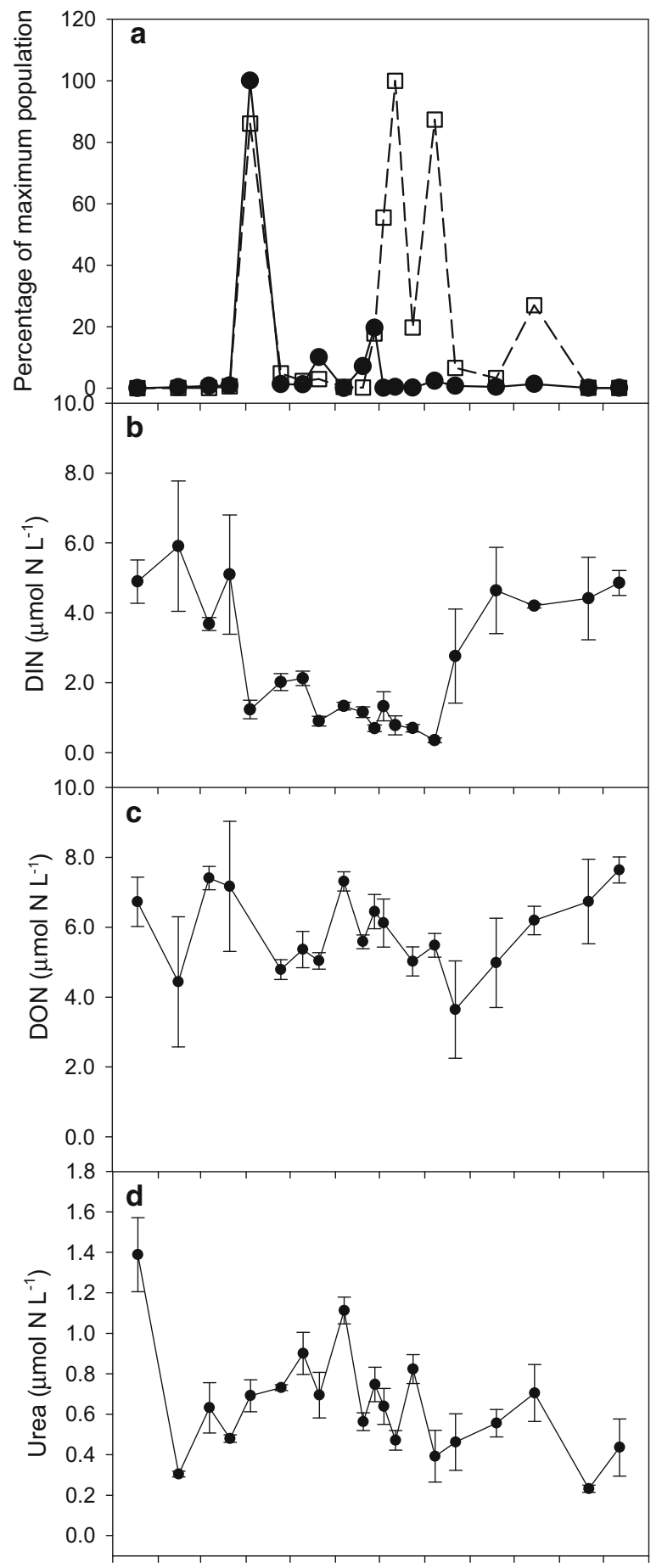

Jan Feb Mar Apr May Jun Jul Aug Sep Oct Nov Dec Jan Date

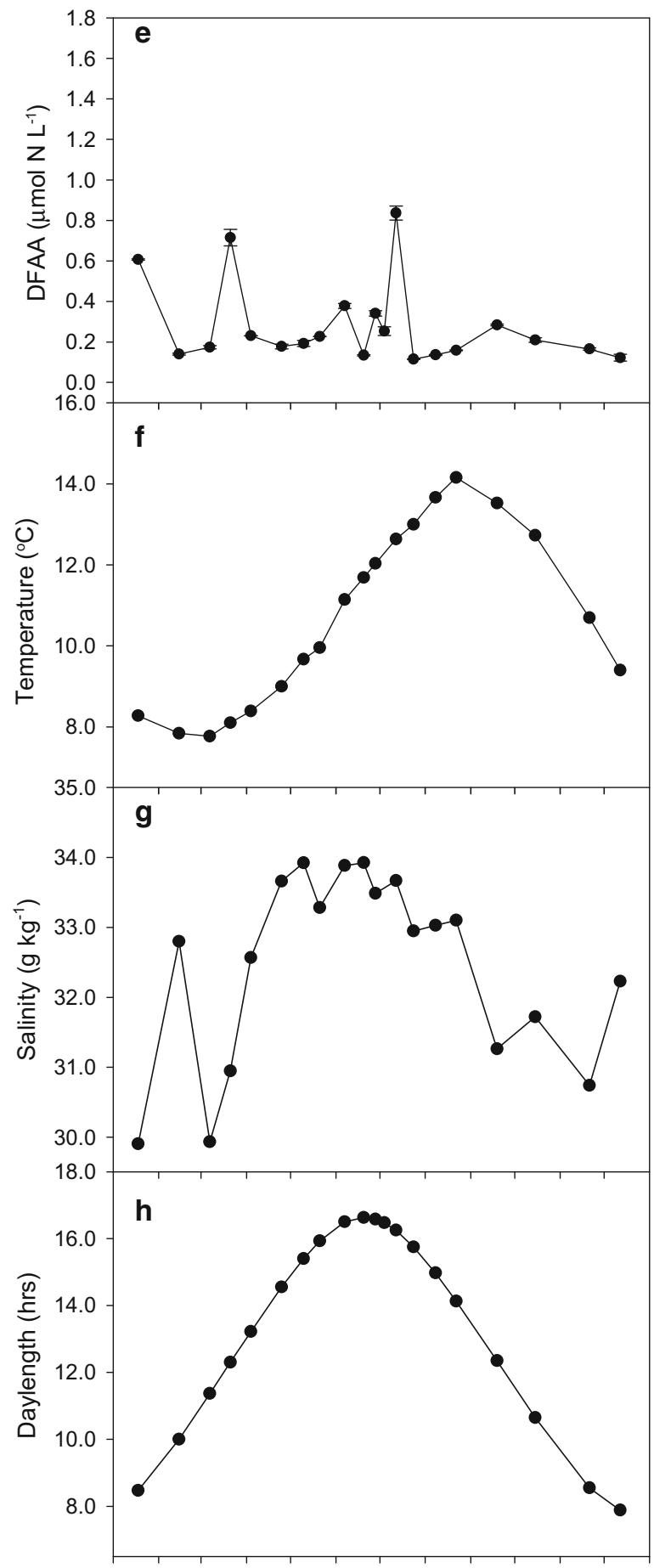

Jan Feb Mar Apr May Jun Jul Aug Sep Oct Nov Dec Jan Date 
४Fig. 2 Seasonal patterns in (a) percentage of maximum recorded abundance of the spring group (solid line, closed circles) and summer/autumn group (dashed line, open squares) and the parameters with which the multivariate pattern of community composition and abundance of 6 selective taxa representative of these two groups were correlated: b DIN, c DON, d urea, e DFAA, f temperature, $\mathbf{g}$ salinity, h daylength/ photoperiod. Error bars are standard errors. Please note the change in scale from DIN and DON to urea and DFAA

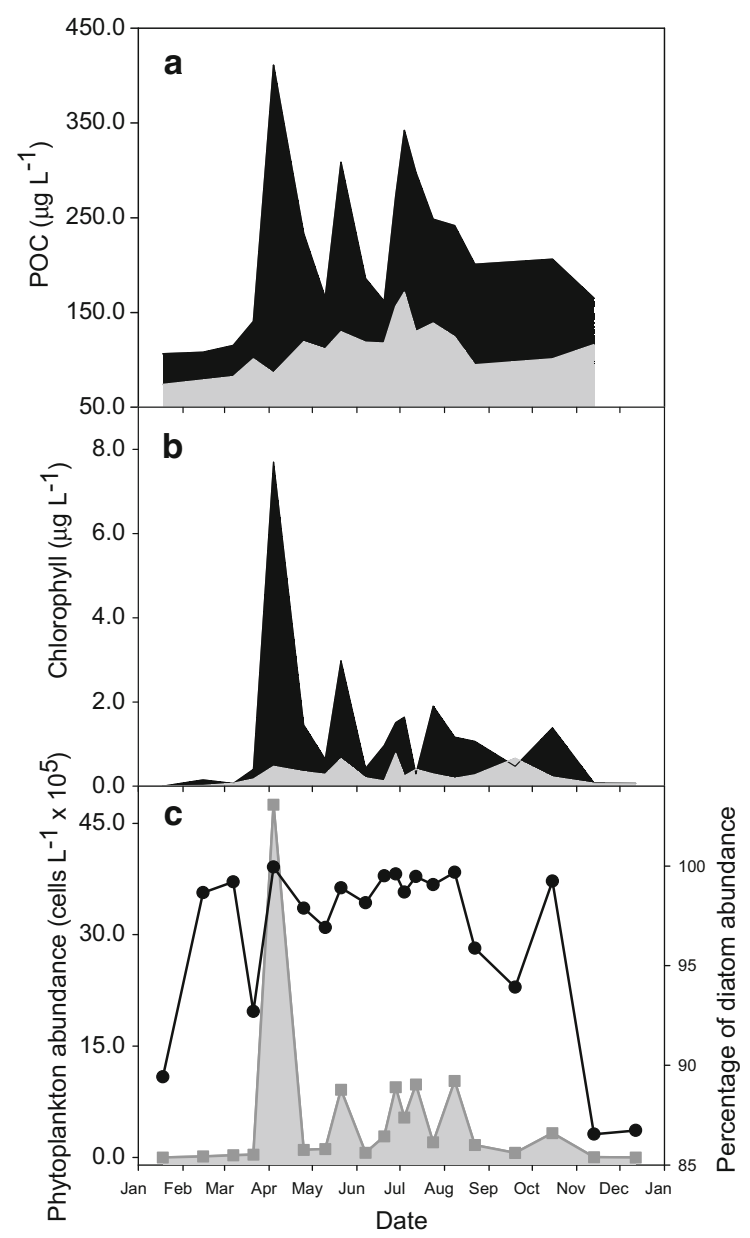

Fig. 3 Seasonal microbial and phytoplankton biomass and abundance in Loch Creran in 2012. a Microbial biomass of the $>10 \mu \mathrm{m}$ size fraction (black area) and the $<10 \mu \mathrm{m}$ size fraction (grey area). The two areas together make up the microbial biomass of the $<200 \mu \mathrm{m}$ fraction. b Phytoplankton biomass, as chlorophyll concentration, of the $>10 \mu \mathrm{m}$ size fraction (black area) and the $<10 \mu \mathrm{m}$ size fraction (grey area). The two areas together make up the phytoplankton biomass of the $<200 \mu \mathrm{m}$ fraction. c Phytoplankton abundance of all enumerated taxa (grey area, grey squares), and diatom abundance as a percentage of the total phytoplankton abundance (solid line, black circles)
Scrippsiella spp. Balech ex Loeblich III with peaks in their abundance in spring $\left(34.8 \times 10^{5}\right.$ cells $\left.\mathrm{L}^{-1}\right)$ and summer $\left(4 \times 10^{3}\right.$ cells $\left.\mathrm{L}^{-1}\right)$ respectively. The highest abundances across all enumerated taxa were reached by Skeletonema spp. and Chaetoceros spp. $\left(44 \times 10^{4}\right.$ cells $\left.\mathrm{L}^{-1}\right)$ which encompassed both their coastal and oceanic morphotypes (Hasle and Syvertsen 1997).

The dendogram generated from Cluster analysis (Fig. 4a) showed that the subset of 15 most important taxa could be divided into several groups based on the similarity in their seasonal distribution. At $<10 \%$ similarity between groups (i.e. $>90 \%$ dissimilarity between groups) Fragilariopsis spp. Hustedt stood out in its own group and at $\sim 10 \%$ Ceratulina spp. Peragallo ex Schütt and Dactyliosolen spp. Castracane also formed a separate group. At a cut-off point of $\sim 20 \%$ similarity between groups (i.e. $\sim 80 \%$ dissimilarity), the remaining 12 phytoplankton taxa could be split into two more groups: a group containing the taxa Skeletonema spp., Thalassiosira spp. Cleve, and Pseudo-nitzschia spp. group delicatissima, and a group containing the remaining 9 taxa.

The latter group could be split into three further groups at $40 \%$ similarity between them (Fig. 4a), one of which contained the taxa Chaetoceros spp., Scrippsiella spp., and Pseudo-nitzschia spp. group seriata. These 6 taxa were selected for subsequent analysis based on their overall predominance among all enumerated taxa (Table 3) and strong separation in the Cluster (Fig. 4a) and MDS analysis, and were representative of two groups (Table 3; Fig. 4): a spring group containing Skeletonema spp., Thalassiosira spp., and Pseudo-nitzschia spp. group delicatissima and a summer/autumn group containing Chaetoceros spp., Scrippsiella spp., and Pseudonitzschia spp. group seriata. Less abundant diatoms and dinoflagellates of note were Leptocylindus danicus Cleve, which peaked in early summer, and Prorocentrum minimum Pavillard which, despite reaching higher maximum abundance than Scrippsiella spp., only predominated briefly in early spring (Table 3).

The seasonal patterns in abundance of these groups differed (Fig. 4b). Taxa from the first group had peaks and increases in abundance in spring, while taxa from the second group, despite some also having high abundances in spring, had peaks and increases in abundance mostly in late summer and early autumn. 
Biogeochemistry (2017) 134:125-145

133

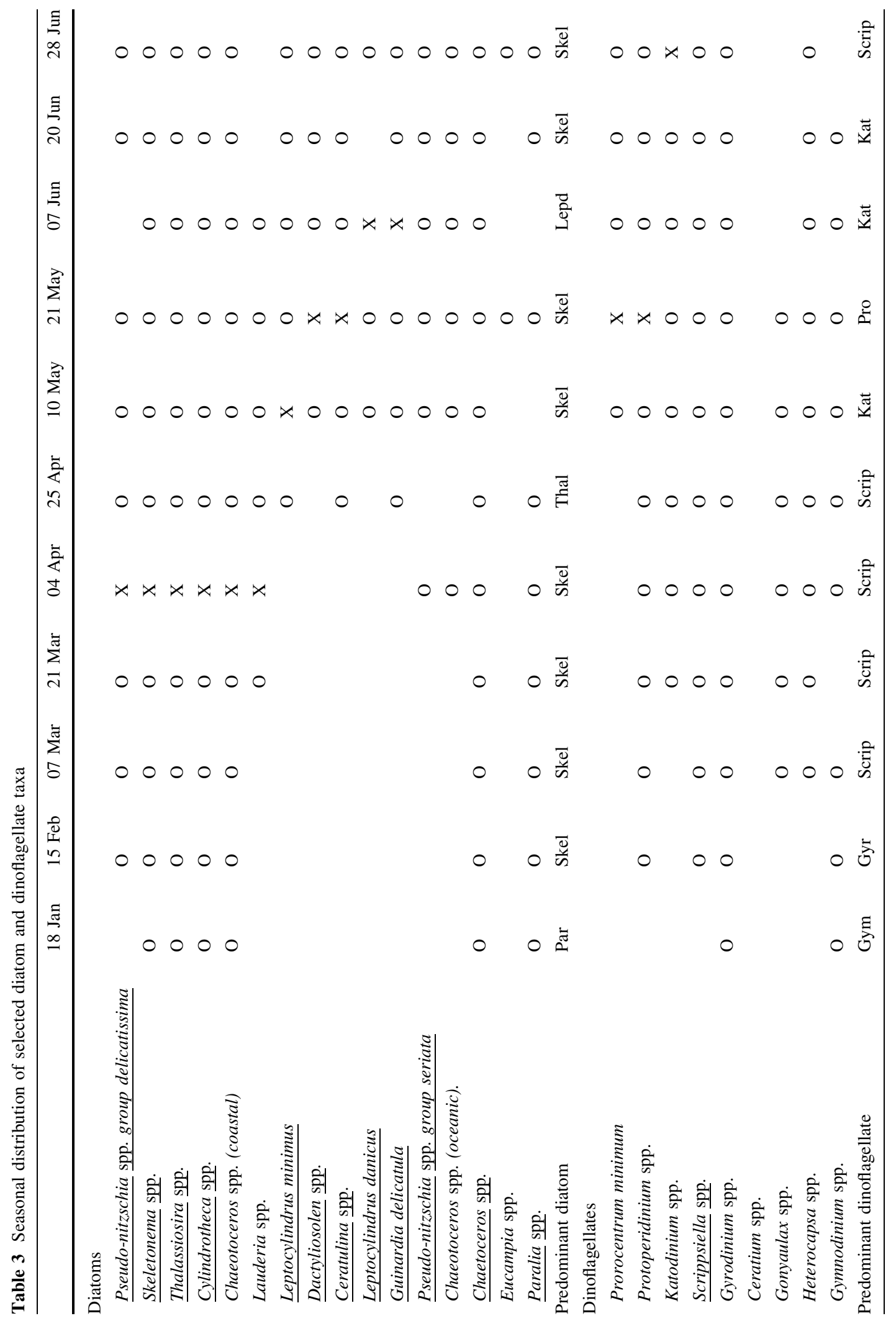

Springer 


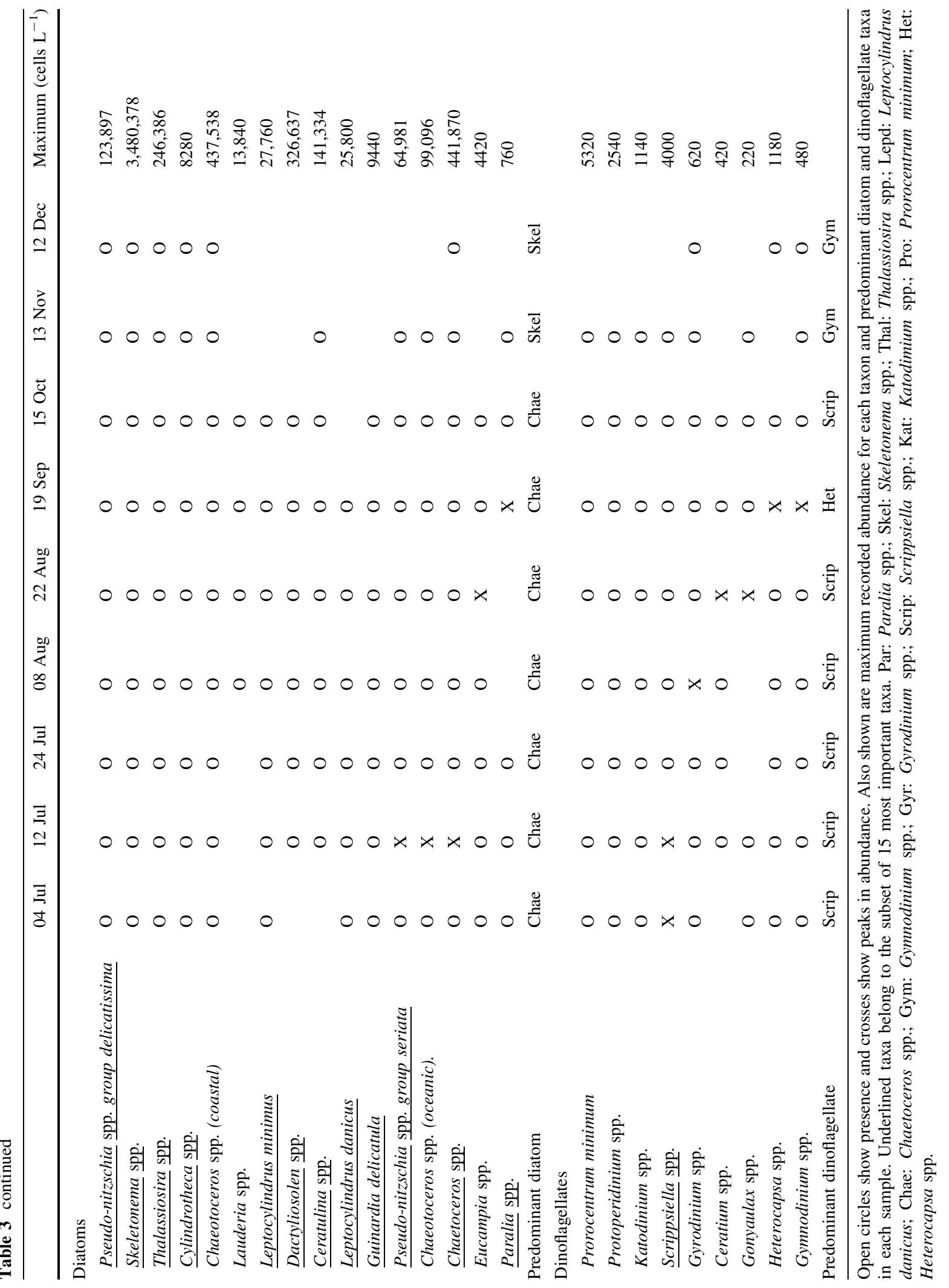


The most abundant taxa in the spring group and summer/autumn groups were Skeletonema spp. and Chaetoceros spp. respectively (Fig. 4b).

Changes in community composition and abundance of these 6 taxa were depicted on an MDS plot (Fig. 5). Statistical comparisons between the multivariate pattern in the community composition of the 6 selected taxa and that of all enumerated taxa revealed that they were very similar $(\mathrm{p}=0.001)$, suggesting that the MSD plot featuring the 6 selected taxa was representative of the entire community. Distances between samples represent their dissimilarity, with larger distances denoting larger dissimilarity. Winter samples transitioned from the left bottom corner of the plot to spring samples on the right side of the plot. Spring samples were not obviously clustered together; most likely because the duration of the spring bloom was brief (Figs. 3, 5). In contrast, late summer and autumn samples were closely clustered together in the top right corner of the plot (Fig. 5). In turn, by November the population had transitioned back to its winter position.

Seasonal peaks in $\mathrm{N}$ uptake rates (Fig. 6) coincided with peaks in microbial biomass and phytoplankton biomass and abundance, but the absolute magnitude and relative uptake varied seasonally and between different $\mathrm{N}$ compounds (Figs. 6,7). $\mathrm{NO}_{3}{ }^{-}$uptake rates by the microbial community were highest during the spring bloom and in late spring and lower in summer (Fig. 6a). Urea uptake rates reached peaks during the spring bloom, late spring, and summer (Fig. 6b). $\mathrm{NH}_{4}{ }^{+}$and DFAA uptake rates were highest in summer (Fig. 6c, d). Generally, the highest $\mathrm{N}$ uptake rates were those of $\mathrm{NH}_{4}{ }^{+}$, followed by urea, DFAA and $\mathrm{NO}_{3}{ }^{-}$. During the spring bloom, urea and $\mathrm{NO}_{3}{ }^{-}$uptake rates were highest followed by those of $\mathrm{NH}_{4}{ }^{+}$and DFAA while in late spring urea uptake rates were also highest followed by those of $\mathrm{NH}_{4}{ }^{+}, \mathrm{NO}_{3}{ }^{-}$and DFAA (Figs. 6 , 7a). In summer, $\mathrm{NH}_{4}{ }^{+}$uptake rates were highest, followed by those of urea. The DFAA summer uptake rates showed substantial increases for the first time, whereas $\mathrm{NO}_{3}{ }^{-}$uptake rates were generally lower than earlier in the season.

The contribution of the $<10 \mu \mathrm{m}$ size fraction to total microbial $\mathrm{N}$ uptake (Fig. 6) was $>50 \%$ at low uptake rates and $<50 \%$ during periods of high uptake rates in spring and summer/autumn, although this varied between different $\mathrm{N}$ compounds. Specifically, the contribution (median \%) of the smaller size fraction to compound specific $\mathrm{N}$ uptake was lowest for $\mathrm{NO}_{3}{ }^{-}(29 \%)$ and highest for the reduced $\mathrm{N}$ forms $\mathrm{NH}_{4}{ }^{+}(46 \%)$, urea (44\%) and DFAA (44\%), especially in summer (Fig. 6). Generally, the smaller microbes took up relatively more urea (up to $59 \%$ ) and $\mathrm{NH}_{4}{ }^{+}$ (up to $55 \%$ ) during the productive season whereas $\mathrm{NO}_{3}{ }^{-}$(up to $56 \%$ ) became more important during autumn and winter (Fig. 7b) when its concentrations were high.

\section{Discussion}

Relationships with environmental parameters

Sequence, or the rate of introduction of allochthonous populations (Smayda 1980), may have had an effect in the spring versus summer/autumn grouping of taxa in Loch Creran in 2012. Chaetoceros spp. was present as two different morphotypes, one that is mainly coastal and one that is mainly oceanic (Hasle and Syvertsen 1997). The abundance of the coastal morphotype peaked in spring and summer and was about four times higher than that of the oceanic morphotype which only peaked in summer (Table 3; Fig. 4b). It is possible that the oceanic morphotype was transported to Loch Creran from offshore waters, as waters of the Firth of Lorne exchange with more ocean influenced shelf water (Fehling et al. 2012, 2006 and references therein). However, once in Loch Creran, its growth would be subjected to the same local environmental conditions that affect the growth of the indigenous flora.

Phytoplankton succession can be driven by several physical and chemical parameters. Those that correlated with the multivariate pattern in community composition and abundance in Loch Creran were, in order of statistical importance: urea, daylength, temperature, DFAA, salinity, DON, and DIN (Table 2). Temperature and daylength varied seasonally in a typical and predictable sinusoidal fashion (Fig. 2), and are frequently identified as important factors influencing phytoplankton species composition (Boyd et al. 2013; Eppley 1972; Fehling et al. 2005; Karentz and Smayda 1984; Lomas and Glibert 1999a, b).

Salinity in Loch Creran varies with the intensity and frequency of rainfall (unpublished data). Nutrient concentrations in temperate coastal areas that receive freshwater inputs may be expected to vary with salinity, with the relationship being stronger in winter 
a

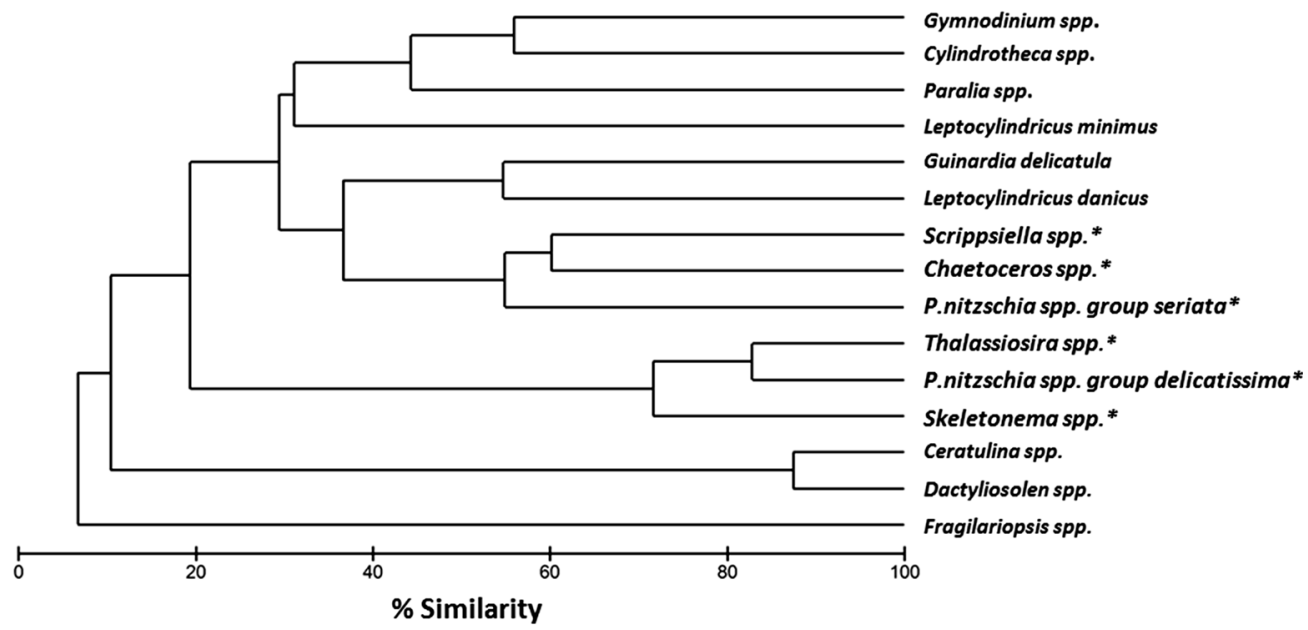

b

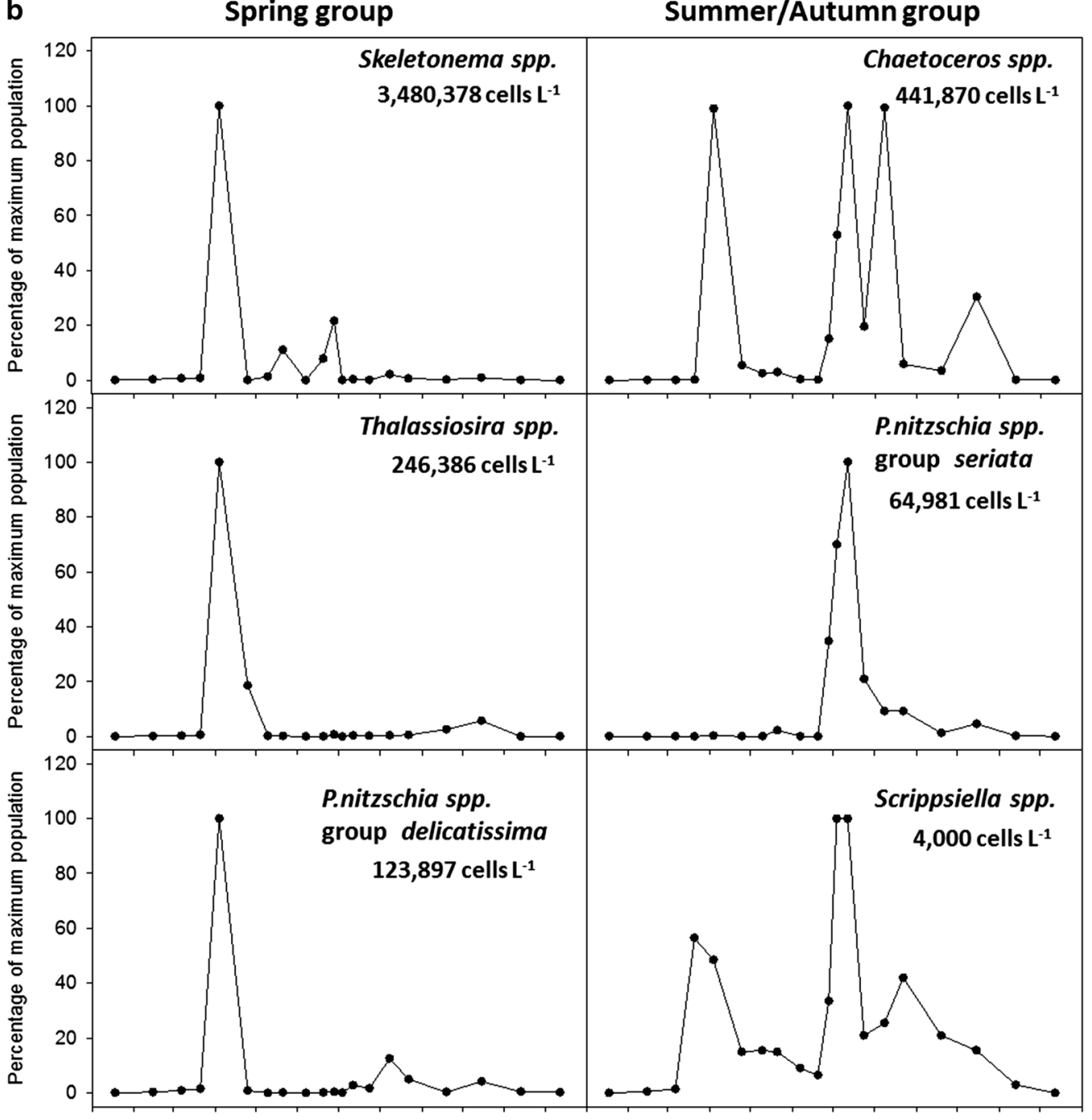

Jan Feb Mar Apr May Jun Jul Aug Sep Oct Nov Dec Jan Feb Mar Apr May Jun Jul Aug Sep Oct Nov Dec Jan Date
Date 
4Fig. 4 Group classification of the 15 most important taxa in Loch Creran in 2012. a Dendrogram generated by cluster analysis based on a Bray-Curtis similarity matrix of abundance data from the subset of 15 taxa. b Seasonal patterns in the percentage of maximum recorded population for 6 selected taxa (asterisks) representative of groups identified from the cluster analysis. Maximum recorded abundance for each taxon is shown (cells $\mathrm{L}^{-1}$ )

and weaker in spring and summer when biological growth exerts a greater influence. In Loch Creran, Solórzano and Ehrlich (1979) found inverse correlations between salinity and the concentrations of DIN, DIS and DON, especially during the autumn and winter months. The effect of salinity in these months on nutrient concentrations is also evident in this study: from the end of August salinity decreased over the autumn and DIN (Fig. 2b), DON (Fig. 2c), DIP and DIS (not shown) concentrations began to increase back to their winter levels. Also, in winter there was an obvious relationship between salinity and DON concentrations, with an increase in salinity on 15 February coinciding with a decrease in DON concentrations.

In several temperate coastal and shelf sea systems, such as the North Sea (Johnson et al. 2012; Van Engeland et al. 2010), English Channel (Butler et al. 1979), Irish Sea (Moschonas et al. 2015) and Chesapeake Bay (Bronk et al. 1998), total DON concentrations follow a seasonal trend in which DON increases in spring or summer, during or following the drawdown of DIN by phytoplankton production, and is subsequently decreases over the course of several weeks or months.

During this study, DON concentrations reached a maximum at the beginning of June and then gradually decreased to a minimum at the end of August, like the gradual DON drawdown observed in the above

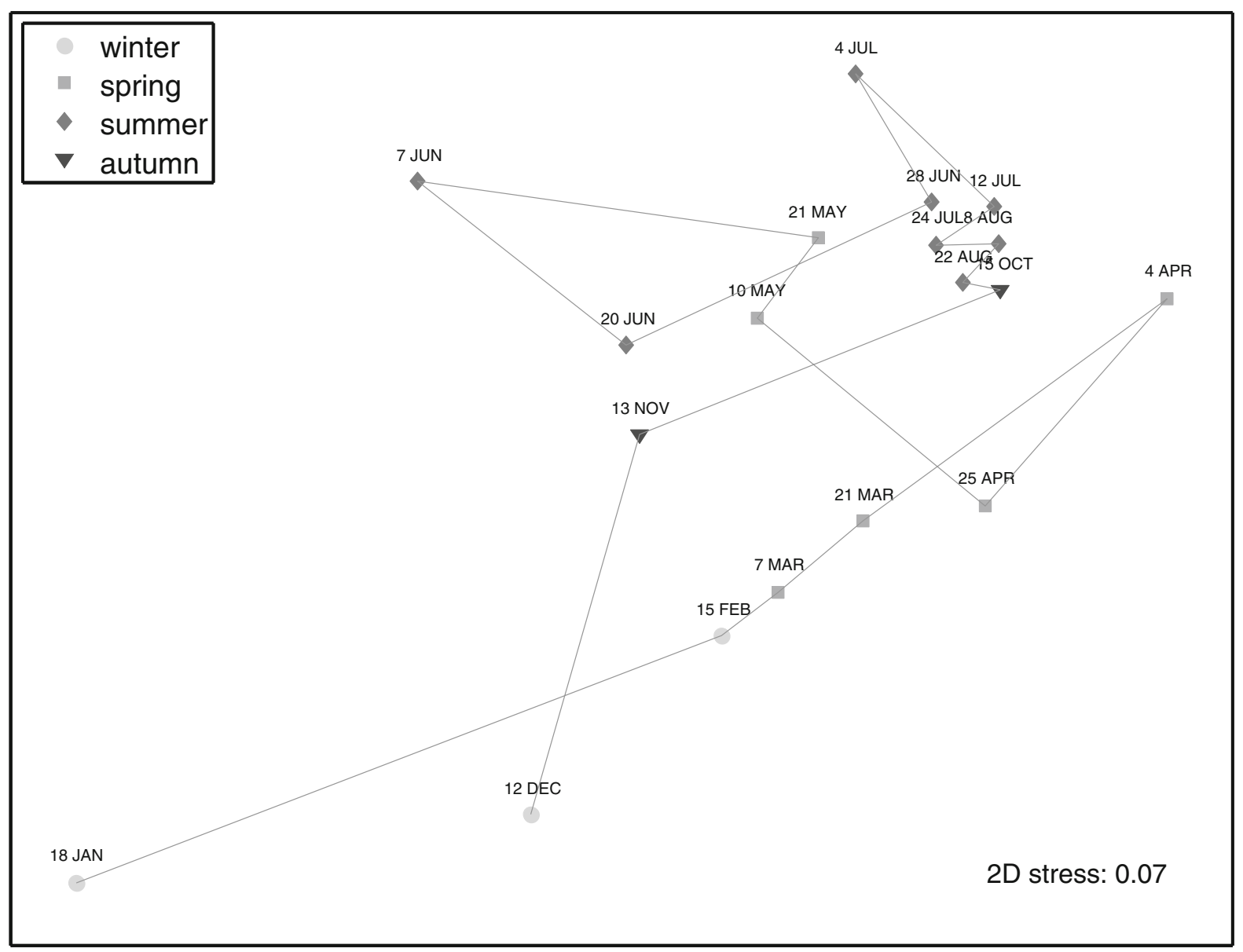

Fig. 5 MDS plot of $\log (x+1)$ transformed abundance of the 6 selected taxa representative of groups identified by cluster analysis based on a Bray-Curtis similarity matrix. Lines connect consecutive sample dates 


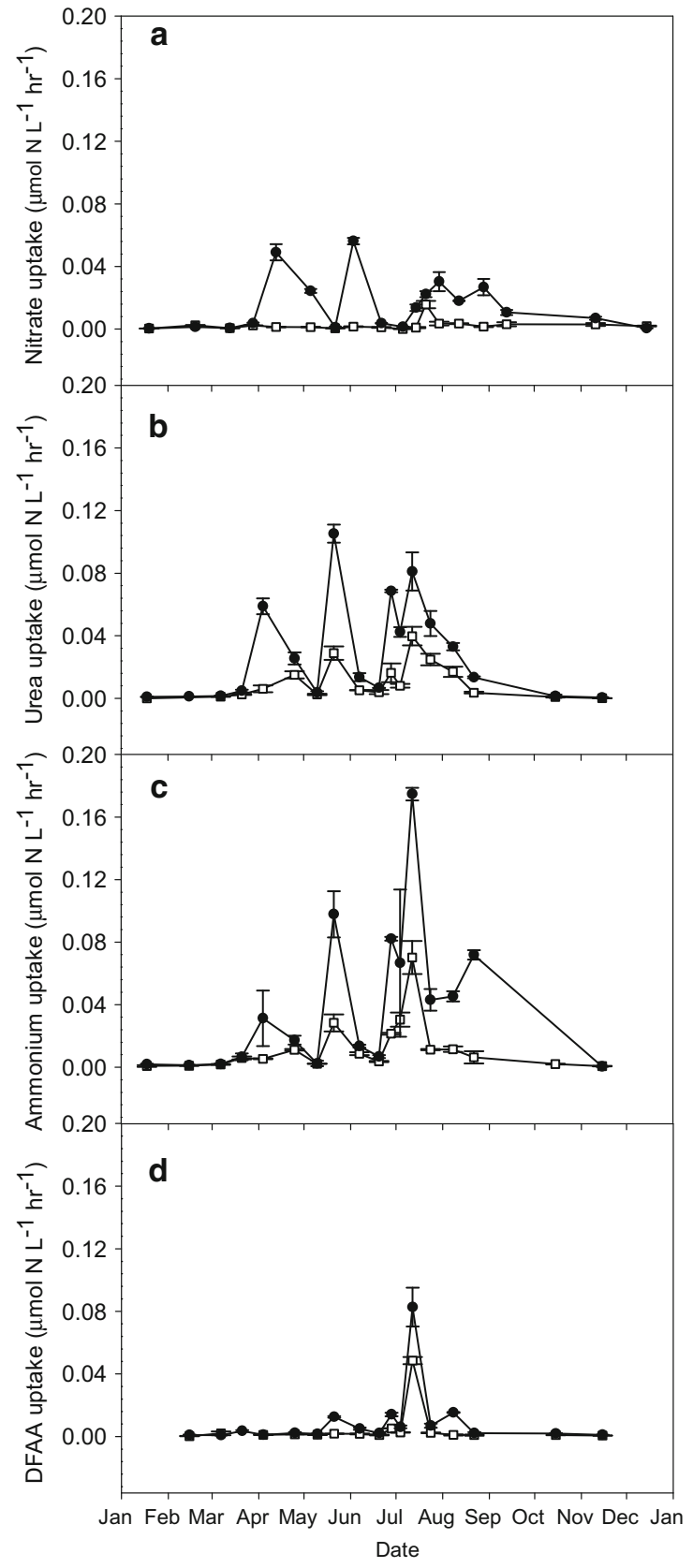

Fig. 6 Seasonal patterns in N uptake by the $<200 \mu \mathrm{m}$ size fraction (closed circles) and the $<10 \mu \mathrm{m}$ size fraction (open squares) from $\mathrm{NO}_{3}{ }^{-}$, urea, $\mathrm{NH}_{4}{ }^{+}$, and DFAA in Loch Creran in 2012. Error bars are standard errors

studies. The bulk of DON that was gradually remineralised during the summer months can be classified as semi-labile DON. Generally, semi-labile DON has turnover times of weeks to months (Carlson and Hansell 2015; Johnson et al. 2012; Lønborg et al.

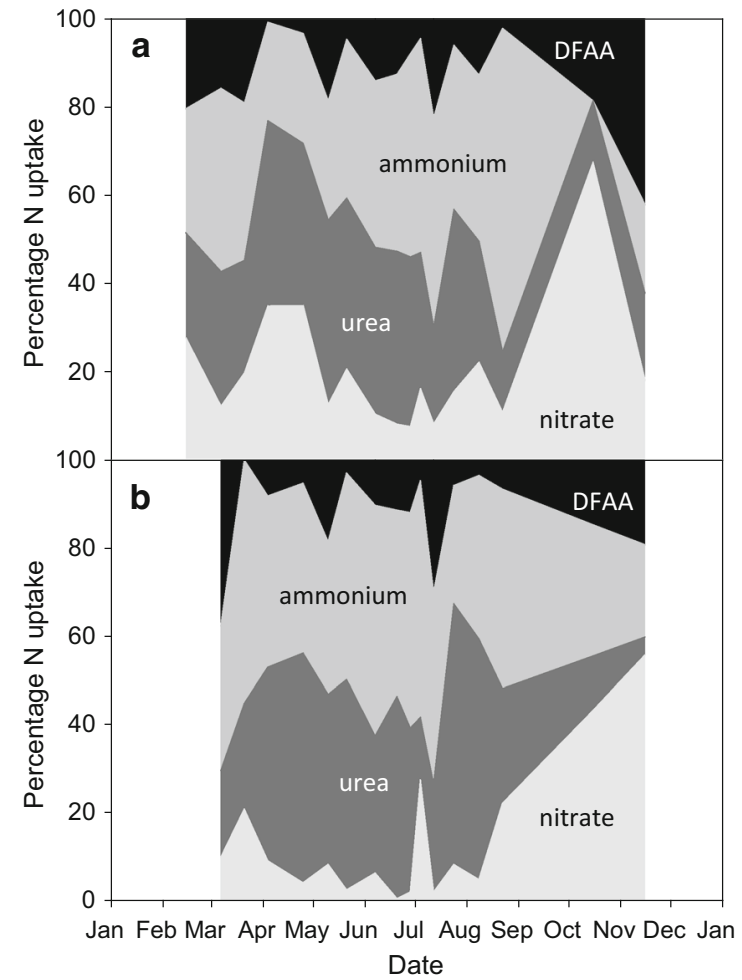

Fig. 7 Seasonal patterns in the proportion of total measured $\mathrm{N}$ uptake accounted for by $\mathrm{NO}_{3}{ }^{-}$, urea, $\mathrm{NH}_{4}{ }^{+}$, and DFAA in a the $<200 \mu \mathrm{m}$ size fraction and $\mathbf{b}$ the $<10 \mu \mathrm{m}$ size fraction in Loch Creran in 2012. a $\mathrm{NO}_{3}{ }^{-}(8-68 \%)$, urea (14-42\%), $\mathrm{NH}_{4}{ }^{+}$ (0-73\%), DFAA (1-42\%). b $\mathrm{NO}_{3}{ }^{-}$(1-56\%), urea (4-59\%), $\mathrm{NH}_{4}{ }^{+}(21-55 \%)$, DFAA $(0-38 \%)$

2009a, b) and is accessible mainly to bacteria (Bronk et al. 2007).

Urea and DFAA concentrations remained low throughout the year and accounted for between 6 and $30 \%$ of total DON concentration. Urea and DFAA are labile DON compounds with high turnover rates which prevent them from accumulating in high concentrations (Bronk et al. 2007; Sipler and Bronk 2015). Semi-labile and refractory DON compounds such as proteins, amino polysaccharides and humic substances turn over much slower and therefore have higher concentrations, although there are now indications that some humic substances may be highly bioavailable (See et al. 2006). The turnover times for urea and DFAA between March and October were 1-34 and 1-19 h respectively, with both compounds having turnover times of less than $7 \mathrm{~h}$ on most dates. This means that during the productive season the entire urea and DFAA stocks in Loch Creran were turned over in 
less than a day and a half, and most often in less than $7 \mathrm{~h}$.

\section{Seasonal phytoplankton distribution}

Within the constraints of inter-annual variability, phytoplankton biomass and abundance in Loch Creran exhibits a seasonal cycle characteristic of temperate coastal waters, with a bloom in early spring and smaller blooms in summer and early autumn (Tett and Wallis 1978). In 2012, the microbial and phytoplankton biomass of the $<10 \mu \mathrm{m}$ size fraction remained relatively constant, while the biomass of the $>10 \mu \mathrm{m}$ size fraction fluctuated in time, and was mostly responsible for the blooms in spring and summer/autumn (Fig. 3a, b). The biomass of the smaller phytoplankton size fractions is relatively stable over time (Chisholm 1992; Raimbault et al. 1988) because it is generally more tightly controlled by grazing (Barber and Hiscock 2006; Fogg 1991; Glibert 1993; Smetacek 2002). In contrast, the biomass of the larger size fractions oscillates considerably over time (Fenchel 1988; Fogg 1991; Smetacek 2002) affected by environmental parameters such as $\mathrm{NO}_{3}{ }^{-}$concentration (Maguer et al. 2009; Malone 1971; Wilkerson et al. 2000).

The abundance of phytoplankton taxa that were identified and enumerated by light microscopy were predominantly larger cells $>10 \mu \mathrm{m}$ and were comprised mainly of diatoms. Diatoms are thought to prefer wellmixed, nutrient replete conditions (although see Kemp and Villareal (2013) for a different view), in contrast to stratified nutrient-limited conditions that are thought to favour dinoflagellates (Falkowski et al. 2004; Margalef 1978; Tozzi et al. 2004). There are numerous physiological reasons why diatoms may thrive under $\mathrm{NO}_{3}{ }^{-}$-rich conditions (Glibert et al. 2016 and references therein). For example, they generally have more $\mathrm{NO}_{3}{ }^{-}$transporters than other phytoplankton taxa and higher rates of $\mathrm{NO}_{3}{ }^{-}$reductase activity (e.g., Song and Ward 2007; Lomas and Glibert 1999b). Diatoms also dominate under conditions of cool temperature. While cool temperatures may be less favourable for photosynthesis, diatoms are thought to be able to regulate overall cellular energy balance in cool water through the reduction of $\mathrm{NO}_{3}{ }^{-}$to $\mathrm{NO}_{2}{ }^{-}$and even $\mathrm{NH}_{4}{ }^{+}$via a nonassimilatory pathway that complements their use of $\mathrm{NO}_{3}{ }^{-}$in a nutritionally assimilatory mode (e.g., Lomas and Glibert 1999a, b; Parker and Armbrust 2005; Kamp et al. 2011; Glibert et al. 2016).
Loch Creran is a shallow and tidally mixed fjord typical of Scottish waters, which only stratifies periodically because of lower salinity at the surface (Fehling et al. 2006; Gowen et al. 1983), and has nutrient concentrations that rarely fall below their limit of detection, even in the relatively dry summer months (Fig. 2). The intermittent mixing and stratification and perhaps resupply of new $\mathrm{N}$ may be why diatoms predominate in the cool, $\mathrm{NO}_{3}{ }^{-}$-rich waters of the loch. However, the phytoplankton community in coastal waters is generally subject to long-term variability (e.g. Bresnan et al. 2009), and the balance between diatoms and flagellates in Loch Creran may be changing (Whyte et al. 2016).

The 6 most abundant taxa, Skeletonema spp., Thalassiosira spp., Pseudo-nitzschia spp. group delicatissima, Chaetoceros spp., Scrippsiella spp., and Pseudo-nitzschia spp. group seriata. are prominent members of the phytoplankton community in Scottish and other temperate coastal waters worldwide; and similar spring-summer/autumn successional patterns involving them have been documented before (Borkman and Smayda 2009; Bresnan et al. 2009; Gowen, et al. 2012b; Henriksen 2009; Smayda 1980). The nontoxic Pseudo-nitzschia spp. group delicatissima occurred mainly in spring, and the potentially toxic Pseudo-nitzschia spp. group seriata mainly in summer (Table 2; Fig. 4b). It is of note that P. minimum is also an important HAB species (Heil et al. 2005; Glibert et al. 2012), although its occurrence was comparatively short-lived. Some Pseudo-nitzschia species can produce the neurotoxin domoic acid which, when concentrated by filter-feeding shellfish and is ingested by humans, can result in Amnesic Shellfish Poisoning (Davidson et al. 2011). The Scottish west coast is a region of shellfish aquaculture and Pseudo-nitzschia are actively monitored. Our findings agree with the pattern of Pseudo-nitzschia dominance observed by Fehling, et al. (2006) in the Firth of Lorne, adjacent to Loch Creran.

\section{Seasonal patterns in uptake of different forms of $\mathrm{N}$}

In temperate coastal systems, the magnitude of $\mathrm{N}$ uptake, the main form of $\mathrm{N}$ utilised, and the predominant phytoplankton taxa can vary seasonally. For example, in Chesapeake Bay, evidence shows that phytoplankton take up mainly allochthonous new $\mathrm{N}$, as $\mathrm{NO}_{3}{ }^{-}$, in spring and autochthonous regenerated $\mathrm{N}$ 
in summer and autumn (McCarthy et al. 1977; Bronk et al. 1998). In the Norwegian Oslofjord, Paasche and Kristiansen (1982) found a similar trend and observed that $\mathrm{N}$ uptake rates were highest in the summer. Berg et al. (2003) investigated relationships between phytoplankton functional groups and seasonal uptake of different $\mathrm{N}$ forms in the brackish Gulf of Riga, and found that $\mathrm{NO}_{3}{ }^{-}$uptake was correlated with the relative abundance of diatoms, while regenerated $\mathrm{N}$ in the form of $\mathrm{NH}_{4}{ }^{+}$, urea and amino acids was correlated with that of dinoflagellates, cryptophytes, and cyanobacteria. Similar reports of dichotomous use of different forms of $\mathrm{N}$ have been frequently reported. Glibert et al. (2004) reported the same phenomenon from Florida Bay, as did Domingues et al. (2011) for a tidal fresh estuary. Similar observations have been reported from mesocosm experiments variably enriched with different forms of N (e.g. Donald et al. 2011, 2013; Fawcett and Ward 2011; Glibert et al. 2014b, 2016).

Our results demonstrated that urea and $\mathrm{NO}_{3}{ }^{-}$were used at highest rates in spring, $\mathrm{NH}_{4}{ }^{+}$was used at highest rates in summer/autumn, and overall $\mathrm{N}$ uptake rates were generally highest in summer. The generally accepted view is that new $\mathrm{N}_{\text {as }} \mathrm{NO}_{3}{ }^{-}$is important in spring and regenerated $\mathrm{N}$ in summer (e.g., Glibert 1997 and references therein). Urea uptake rates may be expected to be relatively low during the spring bloom given the literature status of urea as a regenerated nutrient. However, this study shows that urea uptake rates can be highest relative to other $\mathrm{N}$ sources during the spring bloom, up to $44 \%$ of the total $\mathrm{N}$ uptake. There are indications that this may also be the case during spring in the Canadian Arctic (Simpson et al. 2013) and during an induced Phaeocystis bloom in a Norwegian fjord (Sanderson et al. 2008). The recent identification of a urea cycle in diatoms may be relevant in this regard (e.g., Armbrust et al. 2004; Allen et al. 2011); whereas the urea cycle in mammals serves to remove excess $\mathrm{N}$, in diatoms it appears to also play an important role in the fixation of $\mathrm{C}$ and $\mathrm{N}$ and the rapid metabolic response following short-term nutrient withdrawal or introduction.

In addition to the high absolute and relative urea uptake rates during the spring bloom (Figs. 6b, 7a), a considerable portion of the total DON pool contributed potentially new $\mathrm{N}$ from winter DON highs to spring production as seen from the drop in DON concentration (Fig. 2c). We estimate that the drawdown of DON during the spring bloom could have contributed up to $2.6 \pm 0.4 \mu \mathrm{mol} \mathrm{N} \mathrm{L}{ }^{-1}$ compared to $4.5 \pm 1.9 \mu \mathrm{mol} \mathrm{N} \mathrm{L}{ }^{-1}$ from $\mathrm{NO}_{3}{ }^{-}$, i.e. 37 and $63 \%$ respectively of the total measured dissolved $\mathrm{N}$ drawdown.

Urea uptake remained relatively high in summer and autumn (up to $41 \%$ of the total measured dissolved $\mathrm{N}$ drawdown, Fig. 7a), and this finding adds to evidence suggesting that urea is of importance for phytoplankton $\mathrm{N}$ nutrition year-round (Glibert et al. 2006, 2014a; Lomas et al. 2002; Solomon et al. 2010). In addition, our results uniquely suggest that this is the case even in a near-pristine location leading to the conclusion that urea inputs from anthropogenic sources may boost processes which are naturally occurring and highly important to local production. It is of note that rates of $\mathrm{NO}_{3}{ }^{-}$uptake herein may potentially have been underestimated due to the necessity of conducting the incubations in the afternoon and the known diel component of $\mathrm{NO}_{3}{ }^{-}$uptake (e.g., Berges et al. 1995; Glibert et al. 1991, 2016).

The $<10 \mu \mathrm{m}$ size fraction contributed substantially to total $\mathrm{N}$ uptake (Fig. 6), and was higher for regenerated $\mathrm{N}$ rather than $\mathrm{NO}_{3}{ }^{-}$(Fig. 7). Evidence suggests that although primary production by the smaller size fractions is important and often dominant, especially in oligotrophic regions, the contribution of the larger size fraction increases and often dominates in coastal waters, where $\mathrm{NO}_{3}{ }^{-}$levels are higher (Lomas and Glibert 1999a; Maguer et al. 2009; Malone 1971; Wilkerson et al. 2000). Also, the smaller size fractions appear to contribute more to regenerated $\mathrm{N}$ uptake, while the larger size fractions to new N uptake (Glibert et al. 2016; Joint et al. 1986; Joubert et al. 2011). Our data show that in the $<10 \mu \mathrm{m}$ fraction, $\mathrm{NO}_{3}{ }^{-}$contributed little to $\mathrm{N}$ uptake (up to $28 \%$ during spring and summer but generally much lower, Fig. 7b), but $\mathrm{NH}_{4}{ }^{+}$(up to $55 \%$ ), urea (up to $59 \%$ ), and DFAA (up to $38 \%$ ) did considerably during spring and summer (Fig. 7b), especially in the summer when regenerated $\mathrm{N}$ uptake rates were highest (Fig. 6). There are several possible physical (e.g. diffusion limitation) and biochemical (e.g. assimilation pathways) reasons why different size classes may prefer different forms of $\mathrm{N}$, and this is an area of research that requires further study.

Bacteria are important components of the microbial community and probably contributed to $\mathrm{N}$ uptake and interacted with phytoplankton. The traditional model 
of $\mathrm{N}$ uptake in the marine environment used to classify inorganic $\mathrm{N}$ uptake as a phytoplankton process and organic $\mathrm{N}$ uptake as a bacterial process, but the paradigm has now changed (Zehr and Ward 2002). Phytoplankton can clearly assimilate organic $\mathrm{N}$ and bacteria inorganic N. Specifically, bacteria tend to take up more reduced than oxidised inorganic $\mathrm{N}$ while at the same time regenerating $\mathrm{NH}_{4}{ }^{+}$; also, different bacterial phylogenetic groups may be responsible for uptake of different N compounds (Kirchman 2000). Additionally, bacterially produced extracellular enzymes can break down complex $\mathrm{N}$ compounds which in turn can be taken up by both bacteria and adjacent phytoplankton (Arnosti 2011).

The differences in $\mathrm{N}$ uptake between spring and summer/autumn were associated with two statistically separate phytoplankton groups: the spring group was associated with increased uptake rates of new $\mathrm{N}$ and the summer/autumn group with increased uptake rates of regenerated N. Regenerated inorganic N and DON have been connected to the development of HABs. Supporting evidence comes from laboratory and field studies which found that regenerated $\mathrm{N}$ is associated with dinoflagellates (most HAB species are dinoflagellates), and that DON supports the growth of some HAB species (Davidson et al. 2012 and references therein). In this study, uptake rates of regenerated inorganic $\mathrm{N}$ were highest in summer/autumn when the potentially toxic diatom Pseudo-nitzschia spp. group seriata was most abundant.

\section{Summary and conclusion}

$\mathrm{N}$ uptake rates and total DON concentration patterns suggested high utilisation throughout the year with a mainly labile profile in spring and semi-labile profile in summer. Urea uptake rates were high in both spring and summer/autumn, even when water column concentrations were low while DFAA uptake rates were generally very low but increased briefly mid-summer. The higher urea uptake rates and drawdown of total DON during the spring bloom were unexpected and suggest that this fraction of DON not only naturally contributes to regenerated production but can also contribute substantially to new production. The $>10 \mu \mathrm{m}$ fraction contributed most to the uptake of new $\mathrm{N}$ rather than regenerated $\mathrm{N}$, especially in summer/autumn. In contrast the $<10 \mu \mathrm{m}$ fraction took up mostly regenerated $\mathrm{N}$. The $<10 \mu \mathrm{m}$ fraction formed a constant background of microbial and phytoplankton biomass, important at low total biomass levels, but exceeded by the larger size fraction during phytoplankton blooms in spring and summer/autumn. We identified two statistically significant phytoplankton groups, mostly belonging to the larger size fraction, with peaks in spring vs summer/autumn. Their seasonal patterns of community composition and abundance were significantly correlated with urea, daylength, temperature, DFAA, salinity, DON, and DIN. This comprehensive study of seasonal DON biogeochemistry clearly showed that DON was important in the yearly $\mathrm{N}$ cycle, for phytoplankton $\mathrm{N}$ nutrition, and as an environmental variable that influences phytoplankton seasonal distribution and abundance in a near-pristine coastal location. This supplements similar findings from regions with medium (e.g. Irish Sea) and high (e.g. Chesapeake Bay) $\mathrm{N}$ inputs and highlights that DON should be widely studied not only in the context of anthropogenic pressures but also as part of natural ecosystem functioning.

Acknowledgements The authors wish to acknowledge the National Environment Research Council (NERC) for funding and the officers and crew of RV Seòl Mara for assisting with sample collection. This is contribution number 5318 from the University of Maryland Center for Environmental Science.

Open Access This article is distributed under the terms of the Creative Commons Attribution 4.0 International License (http:// creativecommons.org/licenses/by/4.0/), which permits unrestricted use, distribution, and reproduction in any medium, provided you give appropriate credit to the original author(s) and the source, provide a link to the Creative Commons license, and indicate if changes were made.

\section{References}

Allen AE, Dupont CL, Oborník M et al (2011) Evolution and metabolic significance of the urea cycle in photosynthetic diatoms. Nature 473:203-207

Aminot A, Kérouel R (2006) The determination of total dissolved free primary amines in seawater: critical factors, optimized procedure and artefact correction. Mar Chem 98:223-240

Anderson DM, Glibert PM, Burkholder JM (2002) Harmful algal blooms and eutrophication: nutrient sources, composition, and consequences. Estuaries 25:704-726

Antia NJ, Harisson PJ, Oliveira L (1991) The role of dissolved organic nitrogen in phytoplankton nutrition, cell biology and ecology. Phycologia 30:1-89 
Arar EJ, Collins GB (1997) Method 445.0: in vitro determination of Chlorophyll a and Pheophytin a in marine and freshwater algae by fluorescence. National Exposure Research Laboratory Office of Research and Development U.S. Environmental Protection Agency, Cincinnati, $\mathrm{OH}$

Armbrust EV, Berges JA, Bowler C et al (2004) The genome of the diatom Thalassiosira pseudonana: ecology, evolution, and metabolism. Science 306:79-86

Arnosti C (2011) Microbial extracellular enzymes and the marine carbon cycle. Ann Rev Mar Sci 3:401-425

Barber RT, Hiscock (2006) A rising tide lifts all phytoplankton: Growth response of other phytoplankton taxa in diatomdominated blooms. Glob Biogeochem Cycles 20:GB4S03

Berg GM, Balode M, Purina I, Bekere S, Bechemin C, Maestrini SY (2003) Plankton community composition in relation to availability and uptake of oxidized and reduced nitrogen. Aquat Microb Ecol 30:263-274

Berges JA, Cochlan WP, Harrison PJ (1995) Laboratory and field responses of algal nitrate reductase to diel periodicity in irradiance, nitrate exhaustion, and the presence of ammonium. Mar Ecol Prog Ser 124:259-269

Berman T, Bronk DA (2003) Dissolved organic nitrogen: a dynamic participant in aquatic ecosystems. Aquat Microb Ecol 31:279-305

Booth D (1987) Some consequences of a flood tide front in Loch Creran. Estuar Coast Shelf Sci 24:363-375

Borkman DG, Smayda T (2009) Multidecadal (1959-1997) changes in Skeletonema abundance and seasonal bloom patterns in Narragansett Bay, Rhode Island, USA. J Sea Res 61:84-94

Boyd PW, Rynearson TA, Armstrong EA et al (2013) Marine phytoplankton temperature versus growth responses from polar to tropical waters - outcome of a scientific community-wide study. PLoS ONE 8:e63091

Bresnan E, Hay S, Hughes SL et al (2009) Seasonal and interannual variation in the phytoplankton community in the north east of Scotland. J Sea Res 61:17-25

Bronk DA (2002) Dynamics of dissolved organic nitrogen. In: Hansell DA, Carlson CA (eds) Biogeochemistry of marine dissolved organic matter. Academic Press, San Diego

Bronk DA, Glibert PM, Malone TC, Banahan S, Sahlsten E (1998) Inorganic and organic nitrogen cycling in Chesapeake Bay: autotrophic versus heterotrophic processes and relationships to carbon flux. Aquat Microb Ecol 15:177-189

Bronk DA, See JH, Bradley P, Killberg L (2007) DON as a source of bioavailable nitrogen for phytoplankton. Biogeosciences 4:283-296

Butler E, Knox S, Liddicoat M (1979) Relationship between inorganic and organic nutrients in sea-water. J Mar Biol Assoc UK 59:239-250

Carlson CA, Hansell DA (2015) Chapter 3: DOM sources, sinks, reactivity, and budgets. In: Carlson DAHA (ed) Biogeochemistry of marine dissolved organic matter, 2nd edn. Academic Press, Boston, pp 65-126

Chisholm SW (1992) Phytoplankton size. In: Falkowski PG, Woodhead AD (eds) Primary productivity and biogeochemical cycles in the sea. Plenum press, New York, pp 213-239

Clarke KR (1993) Non-parametric multivariate analyses of changes in community structure. Aust J Ecol 18:117-143
Clarke K, Ainsworth M (1993) A method of linking multivariate community structure to environmental variables. Mar Ecol Prog Ser 92:205-219

Clarke KR, Green RH (1988) Statistical design and analysis for a "biological effects" study. Mar Ecol Prog Ser 46:213226

Davidson K, Gilpin L, Hart MC et al (2007) The influence of the balance of inorganic and organic nitrogen on the trophic dynamics of microbial food webs. Limnol Oceanogr 52:2147-2163

Davidson K, Gowen RJ, Tett P (2011) Harmful algal blooms. In: Hester RE, Harrison RM (eds) Marine pollution and human health. Royal Society of Chemistry, Cambridge

Davidson K, Gowen RJ, Tett P et al (2012) Harmful algal blooms: how strong is the evidence that nutrient ratios and forms influence their occurrence? Estuar Coast Shelf Sci 115:399-413

Davidson K, Gilpin LC, Pete R, Brennan D, McNeill S, Moschonas G, Sharples J (2013) Phytoplankton and bacterial distribution and productivity on and around Jones Bank in the Celtic Sea. Prog Oceanogr 117:48-63

Davidson K, Gowen RJ, Harrison PJ, Fleming LE, Hoagland P, Moschonas G (2014) Anthropogenic nutrients and harmful algae in coastal waters. J Environ Manag 146:206-216

Domingues RB, Barbosa AB, Sommer U, Galvão HM (2011) Ammonium, nitrate and phytoplankton interactions in a freshwater tidal estuarine zone: potential effects of cultural eutrophication. Aquat Sci 73:331-343

Donald DB, Bogard MJ, Finlay K, Leavitt PR (2011) Comparative effects of urea, ammonium and nitrate on phytoplankton dominance, community composition and toxicity in a hypereutrophic freshwater. Limnol Oceanogr 56:2161-2175

Donald DB, Bogard MJ, Finlay K, Bunting L, Leavitt PR (2013) Phytoplankton-specific response to enrichment of phosphorus-rich surface waters with ammonium, nitrate, and urea. PLoS ONE 8(1):e53277

Dugdale RC, Goering JJ (1967) Uptake of new and regenerated forms of nitrogen in primary productivity. Limnol Oceanogr 12:196-206

Dugdale RC, Wilkerson FP (1986) The use of $15 \mathrm{~N}$ to measure nitrogen uptake in eutrophic oceans; experimental considerations. Limnol Oceanogr 31:673-689

Eppley RW (1972) Temperature and phytoplankton growth in the sea. Fish Bull US 70:1063-1085

Falkowski PG, Katz ME, Knoll AH, Quigg A, Raven JA, Schofield O, Taylor FJR (2004) The evolution of modern eukaryotic phytoplankton. Science 305:354-360

Fawcett SE, Ward BB (2011) Phytoplankton succession and nitrogen utilization during the development of an upwelling bloom. Mar Ecol Prog Ser 428:13-31

Fehling J, Davidson K, Bates SS (2005) Growth dynamics of non-toxic Pseudo-nitzschia delicatissima and toxic $P$. seriata (Bacillariophyceae) under simulated spring and summer photoperiods. Harmful Algae 4:763-769

Fehling J, Davidson K, Bolch C, Tett P (2006) Seasonality of Pseudo-nitzschia spp. (Bacillariophyceae) in western Scottish waters. Mar Ecol Prog Ser 323:91-105

Fehling J, Davidson K, Bolch CJS, Brand TD, Narayanaswamy BE (2012) The relationship between phytoplankton distribution and water column characteristics in north west european shelf sea waters. PLoS ONE 7:e34098 
Fenchel T (1988) Marine plankton food chains. Annu Rev Ecol Syst 19:19-38

Fitzsimons MF, Lohan MC, Tappin AD, Millward GE (2011) 4.04: the role of suspended particles in estuarine and coastal biogeochemistry. In: Wolanski E, McLusky DS (eds) Treatise on estuarine and coastal science. Academic Press, Waltham, pp 71-114

Fogg GE (1991) The phytoplanktonic ways of life. New Phytol 118:191-232

Glibert PM (1993) The interdependence of uptake and release of $\mathrm{NH}_{4}{ }^{+}$and organic nitrogen. Mar Microb Food Webs 7:53-67

Glibert PM (1997) Interactions of top-down and bottom-up control in planktonic nitrogen cycling. Hydrobiologia 363:1-12

Glibert PM, Capone DG (1993) Mineralization and assimilation in aquatic, sediment, and wetland systems. In: Knowles R, Blackburn TH (eds) Nitrogen isotope techniques, chapter: mineralization and assimilation in aquatic, sediment, and wetland systems. Academic Press, San Diego, pp 243-272

Glibert PM, Goldman JC, Carpenter EJ (1982a) Seasonal variations in the utilization of ammonium and nitrate by photoplankton in Vineyard Sound, Massachusetts, USA. Mar Biol 70:237-249

Glibert PM, Lipschultz F, McCarthy JJ, Altabet MA (1982b) Isotope dilution models of uptake and remineralization of ammonium by marine plankton. Limnol Oceanogr 27:639-650

Glibert PM, Garside C, Fuhrman JA, Roman MR (1991) Dependent coupling of inorganic and organic nitrogen uptake and regeneration in the plume of the Chesapeake Bay estuary and its regulation by large heterotrophs. Limnol Oceanogr 36:895-909

Glibert PM, Heil CA, Hollander D, Revilla M, Hoare A, Alexander J, Murasko S (2004) Evidence for dissolved organic nitrogen and phosphorus uptake during a cyanobacterial bloom in Florida Bay. Mar Ecol Prog Ser 280:73-83

Glibert P, Seitzinger S, Heil C, Burkholder J, Parrow M, Codispoti L, Kelly V (2005) The role of eutrophication in the global proliferation of harmful algal blooms. Oceanography 18:198-209

Glibert PM, Harrison J, Heil C, Seitzinger S (2006) Escalating worldwide use of urea-a global change contributing to coastal eutrophication. Biogeochemistry 77:441-463

Glibert PM, Burkholder JM, Kana TM (2012) Recent insights about relationships between nutrient availability, forms, and stoichiometry, and the distribution, ecophysiology, and food web effects of pelagic and benthic Prorocentrum species. Harmful Algae 14:231-259

Glibert PM, Manager R, Sobota DJ, Bouwman L (2014a) The Haber-Bosch-Harmful algal bloom (HB-HAB) link. Environ Res Lett 9:105001

Glibert PM, Wilkerson F, Dugdale RC, Parker AE, Alexander JA, Blaser S, Murasko S (2014b) Microbial communities from San Francisco Bay Delta respond differently to oxidized and reduced nitrogen substrates: even under conditions that would otherwise suggest nitrogen sufficiency. Front Mar Sci 1, article 17

Glibert PM, Wilkerson FP, Dugdale RC et al (2016) Pluses and minuses of ammonium and nitrate uptake and assimilation by phytoplankton and implications for productivity and community composition, with emphasis on nitrogen-enriched conditions. Limnol Oceanogr 61:165-197

Goeyens L, Kindermans N, Abu Yusuf M, Elskens M (1998) A room temperature procedure for the manual determination of urea in seawater. Estuar Coast Shelf Sci 47:415-418

Goldman JC, Dennett MR (1985) Susceptibility of some marine phytoplankton species to cell breakage during filtration and post-filtration rinsing. J Exp Mar Biol Ecol 86:47-58

Gowen RJ, Tett T, Wood BJB (1983) Changes in the major dihydroporphyrin plankton pigments during the spring bloom of phytoplankton in two Scottish sea-lochs. J Mar Biol Assoc UK 63:27-36

Gowen RJ, Tett P, Bresnan E et al (2012a) Anthropogenic nutrient enrichment and blooms of harmful phytoplankton. In: Barnes M (ed) Oceanography and marine biology, oceanography and marine biology —an annual review. CRC Press, Boca Raton, pp 65-126

Gowen RJ, Tett P, Smayda TJ (2012b) Phytoplankton and the balance of nature: an opinion. Estuar Coast Shelf Sci 113:317-323

Hansell DA, Goering JJ (1989) A method for estimating uptake and production rates for urea in seawater using [14C] and [15 N] urea. Can J Fish Aquat Sci 46:198-202

Hasle GR, Syvertsen EE (1997) Chapter 2: marine diatoms. In: Tomas CR (ed) Identifying marine phytoplankton. Academic Press, San Diego, pp 5-385

Heil CA, Glibert PM, Fan C (2005) Prorocentrum minimum (Pavillard) Schiller: a review of a harmful algal bloom species of growing worldwide importance. Harmful Algae 4:449-470

Henriksen P (2009) Long-term changes in phytoplankton in the Kattegat, the Belt Sea, the Sound and the western Baltic Sea. J Sea Res 61:114-123

Howarth RW (1998) Nutrient limitation of net primary production in marine ecosystems. Annu Rev Ecol Syst 19:89-110

Howarth RW, Marino R (2006) Nitrogen as the limiting nutrient for eutrophication in coastal marine ecosystems: evolving views over three decades. Limnol Oceanogr 51:364-376

IOC, SCOR, IAPSO (2010) The international thermodynamic equation of seawater-2010: calculation and use of thermodynamic properties, Manuals and Guides No. 56. UNESCO

Johnson MT, Greenwood N, Sivyer DB, Thomson M, Reeve A, Weston K, Jickells TD (2012) Characterising the seasonal cycle of dissolved organic nitrogen using Cefas SmartBuoy high-resolution time-series samples from the southern North Sea. Biogeochemistry 113:23-36

Joint IR, Owens NJP, Pomroy AJ (1986) Seasonal production of photosynthetic picoplankton and nanoplankton in the Celtic sea. Mar Ecol Prog Ser 28:251-258

Joubert WR, Thomalla SJ, Waldron HN, Lucas MI, Boye M, Le Moigne FAC, Planchon F, Speich S (2011) Nitrogen uptake by phytoplankton in the Atlantic sector of the Southern Ocean during late austral summer. Biogeosciences 8:2947-2959

Kamp A, de Beer D, Nitsch JL, Lavik G, Stief P (2011) Diatoms respire nitrate to survive dark and anoxic conditions. Proc Natl Acad Sci USA 108:5649-5654

Kanda J, Laws EA, Saino T, Hattori A (1987) An evaluation of isotope dilution effect from conventional data sets of $15 \mathrm{~N}$ uptake experiments. J Plankton Res 9:79-90 
Karentz D, Smayda T (1984) Temperature and seasonal occurrence patterns of 30 dominant phytoplankton species in Narragansett Bay over a 22-year period (1959-1980). Mar Ecol Prog Ser 18:277-293

Kemp AES, Villareal TA (2013) High diatom production and export in stratified waters-a potential negative feedback to global warming. Prog Oceanogr 119:4-23

Kirchman DL (2000) Uptake and regeneration of inorganic nutrients by marine heterotrophic bacteria. In: Kirchman DL (ed) Microbial ecology of the oceans. Lewis Publisher, New York, pp 261-288

Letscher RT, Hansell DA, Carlson CA, Lumpkin R, Knapp AN (2013) Dissolved organic nitrogen in the global surface ocean: distribution and fate. Global Biogeochem Cycles 27:141-153

Lipschultz F (2008) Chapter 31: isotope tracer methods for studies of the marine nitrogen cycle. In: Capone DG, Bronk DA, Mulholland MR, Carpenter EJ (eds) Nitrogen in the marine environment, 2nd edn. Academic Press, San Diego, pp 1345-1384

Lomas MW, Glibert PM (1999a) Interactions between $\mathrm{NH}_{4}{ }^{+}$ and $\mathrm{NO}_{3}{ }^{-}$uptake and assimilation: comparison of diatoms and dinoflagellates at several growth temperatures. Mar Biol 133:541-551

Lomas MW, Glibert PM (1999b) Temperature regulation of nitrate uptake: a novel hypotheses about nitrate uptake and reduction in cool-water diatoms. Limnol Oceanogr 44:556-572

Lomas MW, Trice TM, Glibert PM, Bronk DA, McCarthy JJ (2002) Temporal and spatial dynamics of urea uptake and regeneration rates and concentrations in Chesapeake Bay. Estuaries 25:469-482

Lønborg C, Alvarez-Salgado XA, Davidson K, Miller AEJ (2009a) Production of bioavailable and refractory dissolved organic matter by coastal heterotrophic microbial populations. Estuar Coast Shelf Sci 82:682-688

Lønborg C, Davidson K, Alvarez-Salgado XA, Miller AEJ (2009b) Bioavailability and bacterial degradation rates of dissolved organic matter in a temperate coastal area during an annual cycle. Mar Chem 113:219-226

Maguer J-F, L'Helguen S, Waeles M, Morin P, Riso R, Caradec J (2009) Size-fractionated phytoplankton biomass and nitrogen uptake in response to high nutrient load in the North Biscay Bay in spring. Cont Shelf Res 29:1103-1110

Malone TC (1971) The relative importance of nannoplankton and netplankton as primary producers in tropical oceanic and neritic phytoplankton communities. Limnol Oceanogr 16:633-639

Margalef R (1978) Life-forms of phytoplankton as survival alternatives in an unstable environment. Oceanol Acta 1:493-509

McCarthy JJ, Taylor WR, Taft JT (1977) Nitrogenous nutrition of the plankton in the Chesapeake Bay. I. Nutrient availability and phytoplankton preferences. Limnol Oceanogr 22:996-1011

McDougall TJ, Barker PM (2011) Getting started with TEOS-10 and the Gibbs Seawater (GSW) oceanographic toolbox. Trevor J. McDougall, Sydney

Moschonas G, Gowen RJ, Stewart BM, Davidson K (2015) Nitrogen dynamics in the Irish Sea and adjacent shelf waters: an exploration of dissolved organic nitrogen. Estuar Coast Shelf Sci 164:276-287
Mulholland MR, Lee C (2009) Peptide hydrolysis and the uptake of dipeptides by phytoplankton. Limnol Oceanogr 54:856-868

Mulholland MR, Lomas MW (2008) Chapter 7: nitrogen uptake and assimilation. Nitrogen in the marine environment, 2nd edn. Academic Press, San Diego, pp 303-384

Mulvenna PF, Savidge G (1992) A modified manual method for the determination of urea in seawater using diacetylmonoxime reagent. Estuar Coast Shelf Sci 34:429-438

Owens NJP, Rees AP (1989) Determination of nitrogen-15 at sub-microgram levels of nitrogen using automated continuous-flow isotope ratio mass spectrometry. Analyst 114:1655-1657

Paasche E, Kristiansen S (1982) Nitrogen nutrition of the phytoplankton in the Oslofjord. Estuar Coast Shelf Sci 14:237-249

Parker MS, Armbrust EV (2005) Synergistic effects of light, temperature, and nitrogen source on transcription of genes for carbon and nitrogen metabolism in the centric diatom Thalassiosira pseudonana (Bacillariophyceae). J Phycol 41:1142-1153

Parsons TR, Maita Y, Lalli CM (1984) A manual of chemical and biological methods for seawater analysis. Pergamon Press, New York

Pete R, Davidson K, Hart MC, Gutierrez T, Miller AEJ (2010) Diatom derived dissolved organic matter as a driver of bacterial productivity: the role of nutrient limitation. J Exp Mar Biol Ecol 391:20-26

Raimbault P, Rodier M, Taupier-Letage I (1988) Size fraction of phytoplankton in the Ligurian Sea and the Algerian Basin Mediterranean Sea size distribution versus total concentration. Mar Microb Food Webs 3:1-8

Revilla M, Alexander J, Glibert PM (2005) Urea analysis in coastal waters: comparison of enzymatic and direct methods. Limnol Oceanogr Methods 3:290-299

Ryther JH, Dunstan WM (1971) Nitrogen, phosphorus, and eutrophication in the coastal marine environment. Science 171:1008-1013

Sanderson MP, Bronk DA, Nejstgaard JC, Verity PG, Sazhin AF, Frischer ME (2008) Phytoplankton and bacterial uptake of inorganic and organic nitrogen during an induced bloom of Phaeocystis pouchetii. Aquat Microb Ecol 51:153-168

Seal Analytical (2011a) The automated determination of ammoniacal nitrogen in seawater: QuAAtro method No. Q-069-05 revision 4. Seal Analytical GmBH, Norderstedt, Germany

Seal Analytical (2011b) The automated determination of soluble reactive phosphate in seawater: QuAAtro method No. Q-064-05 revision 4. Seal Analytical GmBH, Norderstedt, Germany

Seal Analytical (2011c) The automated determination of total oxidised nitrogen in seawater: QuAAtro method No. Q-068-05 revision 7. Seal Analytical GmBH, Norderstedt, Germany

Seal Analytical (2011d) The automated determination of silicate in seawater: QuAAtro method No. Q-066-05 revision 3. Seal Analytical GmBH, Norderstedt, Germany

Seal Analytical (2011e) The automated determination of nitrite in seawater: QuAAtro method No. Q-070-05 revision 4. Seal Analytical GmBH, Norderstedt, Germany 
See JH, Bronk DA, Lewitus AJ (2006) Uptake of Spartinaderived humic nitrogen by estuarine phytoplankton in nonaxenic and axenic culture. Limnol Oceanogr 51:2290-2299

Simpson KG, Tremblay J, Brugel S, Price NM (2013) Nutrient dynamics in the western Canadian Arctic. II. Estimates of new and regenerated production over the Mackenzie Shelf and Cape Bathurst Polynya. Mar Ecol Prog Ser 484:47-62

Sipler RE, Bronk DA (2015) Chapter 4: dynamics of dissolved organic nitrogen. In: Carlson DAHA (ed) Biogeochemistry of marine dissolved organic matter, 2nd edn. Academic Press, Boston, pp 127-232

Smayda TJ (1980) Phytoplankton species succession. In: Morris I (ed) The physiological ecology of phytoplankton. Blackwell, Oxford, pp 493-570

Smetacek V (2002) Microbial food webs: the ocean's veil. Nature 419:565

Solomon CM, Collier JL, Berg GM, Glibert PM (2010) Role of urea in microbial metabolism in aquatic systems: a biochemical and molecular review. Aquat Microb Ecol 59:67-88

Solórzano L, Ehrlich B (1979) Chemical investigation of Loch Creran, Scotland-1. Inorganic nutrients, dissolved organic-compounds and pigments. J Exp Mar Biol Ecol 40:1-25

Song B, Ward BB (2007) Molecular cloning and characterization of high-affinity nitrate transporters in marine phytoplankton. J Phycol 43:542-552

Tada K, Tada M, Maita Y (1998) Dissolved free amino acids in coastal seawater using a modified fluorometric method. J Oceanogr 54:313-321

Tappin AD, Millward GE, Fitzsimons MF (2010) Particle-water interactions of organic nitrogen in turbid estuaries. Mar Chem 122:28-38

Taylor JR (1997) An introduction to error analysis: the study of uncertainties in physical measurements. University Science Books, Mill Valley
Tett P, Wallis A (1978) General annual cycle of chlorophyll standing crop in Loch Creran. J Ecol 66:227-239

Tett P, Gowen R, Mills D, Fernandes T, Gilpin L, Huxham M, Kennington K, Read P, Service M, Wilkinson M, Malcolm S (2007) Defining and detecting undesirable disturbance in the context of marine eutrophication. Mar Pollut Bull 55:282-297

Tett P, Portilla E, Gillibrand PA, Inall M (2011) Carrying and assimilative capacities: the ACExR-LESV model for sealoch aquaculture. Aquac Res 42:51-67

Tozzi S, Schofield O, Falkowski P (2004) Historical climate change and ocean turbulence as selective agents for two key phytoplankton functional groups. Mar Ecol Prog Ser 274:123-132

Van Engeland T, Soetaert K, Knuijt A, Laane RWPM, Middelburg JJ (2010) Dissolved organic nitrogen dynamics in the North Sea: a time series analysis (1995-2005). Estuar Coast Shelf Sci 89:31-42

Vitousek PM, Howarth RW (1991) Nitrogen limitation on land and in the sea: how can it occur? Biogeochemistry 13:87-115

Whyte C, Davidson K, Gilpin L, Mitchell E, Moschonas G, McNeill S, Tett P (2016) Tracking changes to a microplankton community in a North Atlantic sea loch using the microplankton index PI(mp). ICES J Mar Sci. doi:10.1093/icesjms/fsw125

Wilkerson FP, Dugdale RC, Kudela RM, Chavez FP (2000) Biomass and productivity in Monterey Bay, California: contribution of the large phytoplankton. Deep Sea Res II 47:1003-1022

WoRMS Editorial Board (2016) World Register of Marine Species. http://www.marinespecies.org at VLIZ. Accessed 2016

Zehr JP, Ward BB (2002) Nitrogen cycling in the ocean: new perspectives on processes and paradigms. Appl Environ Microbiol 68:1015-1024 